\title{
Article \\ Use of Microbial Biostimulants to Increase the Salinity Tolerance of Vegetable Transplants
}

\author{
Alessandro Miceli *(D), Alessandra Moncada *(D) and Filippo Vetrano \\ Dipartimento Scienze Agrarie, Alimentari e Forestali, Università di Palermo, Viale delle Scienze 4, \\ 90128 Palermo, Italy; filippo.vetrano@unipa.it \\ * Correspondence: alessandro.miceli@unipa.it (Alessandro Miceli); alessandra.moncada@unipa.it \\ (Alessandra Moncada); Tel.: +39-091-2386-2219 (Alessandro Miceli); +39-091-2386-2232 (Alessandra Moncada)
}

Citation: Miceli, A.; Moncada, A.; Vetrano, F. Use of Microbial Biostimulants to Increase the Salinity Tolerance of Vegetable Transplants. Agronomy 2021, 11, 1143. https://doi.org/10.3390/ agronomy11061143

Academic Editor:

Małgorzata Szczepanek

Received: 24 May 2021

Accepted: 31 May 2021

Published: 3 June 2021

Publisher's Note: MDPI stays neutral with regard to jurisdictional claims in published maps and institutional affiliations.

Copyright: (c) 2021 by the authors. Licensee MDPI, Basel, Switzerland. This article is an open access article distributed under the terms and conditions of the Creative Commons Attribution (CC BY) license (https:// creativecommons.org/licenses/by/ $4.0 /)$.

\begin{abstract}
Vegetable plants are more sensitive to salt stress during the early growth stages; hence, the availability of poor-quality brackish water can be a big issue for the nursery vegetable industry. Microbial biostimulants promote growth and vigor and counterbalance salt stress in mature plants. This study aimed to evaluate the application of plant growth-promoting microorganisms for improving salt tolerance of lettuce and tomato seedlings irrigated with different water salinity levels $(0,25$, and $50 \mathrm{mM} \mathrm{NaCl})$ during nursery growth. Two commercial microbial biostimulants were applied to the substrate before seeding: $1.5 \mathrm{~g} \mathrm{~L}^{-1}$ of TNC Bactorr ${ }^{\mathrm{S} 13}$ containing $1.3 \times 10^{8} \mathrm{CFU} \mathrm{g}^{-1}$ of Bacillus spp.; $0.75 \mathrm{~g} \mathrm{~L}^{-1}$ of Flortis Micorrize containing $30 \%$ of Glomus spp., $1.24 \times 10^{8} \mathrm{CFU} \mathrm{g}^{-1}$ of Agrobacterium radiobacter, Bacillus subtilis, Streptomyces spp. and $3 \times 10^{5} \mathrm{CFU} \mathrm{g}^{-1}$ of Thricoderma spp. Many morpho-physiological parameters of lettuce and tomato seedlings suffered the negative effect of salinity. The use of the microbial biostimulants modified seedling growth and its response to salt stress. They had a growth-promoting effect on the unstressed seedlings increasing fresh and dry biomass accumulation, leaf number, and leaf area and were successful in increasing salinity tolerance of seedlings especially when using Flortis Micorizze that enhanced salinity tolerance up to $50 \mathrm{mM}$ $\mathrm{NaCl}$. The inoculation of the substrate with microbial biostimulants could represent a sustainable way to improve lettuce and tomato transplant quality and to use brackish water in vegetable nurseries limiting its negative effect on seedling growth.
\end{abstract}

Keywords: vegetable; nursery; seedling; Solanum lycopersium L.; Lactuca sativa L.; salt stress; microorganisms; PGPR; arbuscular mycorrhizal fungi; Trichoderma

\section{Introduction}

Salinity, among the abiotic stresses, invariably has the worst impact in reducing the area of cultivated land and limiting agricultural activity. Fifty percent of the world's arable land is estimated to be affected by salinity by 2050 [1]. Salt stress reduces plant growth due to increasing soil osmotic pressure [2], specific-ion toxicities, and nutritional imbalances [3] or a combination of these factors [4]. These effects can determine severe growth and productivity reductions in most vegetable crops. The salinity threshold of these crops is $\leq 2.5 \mathrm{dS} \mathrm{m}^{-1}$ [5] and can vary according to the species and to many factors such as plant growth stage. Plant sensitivity to salt stress is generally higher at earlier growth stages (seedling, transplant establishment) than at later stages [6]. Thus, growing seedlings under a scarcity of good quality water is a challenge for the nursery vegetable industry. The aim of vegetable transplant growers is to obtain well-developed and vigorous seedlings [7] that can establish and grow fast after transplanting [8,9]. The negative effects of irrigation water salinity on seedling growth can make it hard for the vegetable nursery to reach these goals. Growth reductions determined by salinity can limit the commercial value of transplants as their size has been linked to establishment success, growth rate, and crop yield $[10,11]$. The availability of poor-quality water due to high salt content occurs more and more frequently in many Mediterranean regions (especially those close to the sea) 
where vegetable crops are more widespread, as the intensive draw of irrigation water increases seawater infiltration in groundwater [12].

Many strategies can be used to increase salt tolerance of vegetable crops, such as conventional breeding, gene cloning, and genetic engineering but the complex salinity tolerance mechanism and limited genetic variability that can be found in germplasm lead to limited or no success in alleviating salt stress $[13,14]$. The difficulties found in the development of salt-tolerant cultivars can be ascribed to the lack of knowledge about the genetics of vegetable crops, the composite polygenic nature of the salt tolerance characters, and the wide variation of gene response in different environmental conditions [15].

Many stress response mechanisms activated by plants in response to salt stress (ionic/hydraulic re-equilibrium, detoxification of reactive oxygen species, and modulation of cell growth or cell division) [16] are initiated by hormonal signaling, as proved by the changes of the endogenous concentrations of phytohormones found in plants subject to salt stress $[17,18]$. The stress hormone ethylene has been seen, secreted as root exudates, in all crops under biotic and abiotic stresses [19] and it was shown that it is involved in the regulation of some plant metabolic mechanisms related to significant reductions in plant growth and development under salt stress. Hormone homeostasis is of paramount importance to increase plant tolerance to salinity. Hence, the rebalancing of phytohormone levels through the exogenous application of phytohormones (gibberellins, auxins, and cytokinins) has been suggested as a strategy to increase salt tolerance of vegetable crops and mitigate the negative effects of salinity $[18,20]$. This rebalancing can be achieved by direct supplementation of synthetic plant growth regulators through foliar or root supplementation $[20,21]$ or by inoculating the rhizosphere with microorganisms that produce phytohormones or interact with plants, inducing hormonal changes and modifying plant hormone status [22]. The use of microbial inoculants is becoming a more widely accepted technique for improving the sustainability of intensive agriculture systems. They can act as bio-enhancers or bioprotectants [23] resulting in plant growth promotion and salt stress alleviation and can integrate or substitute agro-chemicals and other conventional agronomic approaches increasing plant efficiency and crop sustainability [24-26].

Many microorganisms have been studied for their plant growth-promoting effect. Microbes can be involved directly or indirectly with plant growth promotion either through improved nutrient acquisition and hormonal stimulation or the suppression of plant pathogens resulting in more vigorous and healthier plants [27]. Many microbes have been isolated from plant-associated microenvironments, such as the rhizosphere, and have been found to exert antagonistic capacity to inhibit the growth of pathogens or to express plant growth-promoting traits, thus, the application of microbial inoculants has gained popularity among researchers and growers. Several microorganisms that can promote plant growth are well-studied in their mode of action and regulation and comprise members of bacterial (Azospirillum, Bacillus, Pseudomonas, Rhizobium, Serratia, Stenotrophomonas, and Streptomyces) or fungal (Ampelomyces, Coniothyrium, and Trichoderma) genera [27]. Besides, arbuscular mycorrhizal fungi (AMF) are the most widespread root fungal symbionts and have a role in the stimulation of plant growth and nutrient uptake of many host plants [28].

Microbial inoculants, also referred to as microbial biostimulants [29], such as plant growth-promoting rhizobacteria (PGPR), arbuscular mycorrhizal fungi (AMF), and Trichoderma spp. are considered useful tools to mitigate the effects of salinity on plant growth and yield $[23,30,31]$. They can directly promote plant growth and improve tolerance to abiotic stresses by increasing nutrient uptake through greater effective root area, solubilization or mineralization of nutrients, biological nitrogen fixation, and iron sequestration through siderophores [32-34]. Moreover, they can produce small peptides, volatiles, and metabolites such as Indole Acetic Acid (IAA) or auxin analogs, Cytokinins, and Gibberellins that can act as phytohormones or growth regulators and affect plant metabolism and development [35-38].

Microbial inoculants have been tested by applying to plants only single strains (e.g., of Bacillus subtilis) or mixtures of microorganisms (e.g., several commercial micro- 
bial biostimulants) [29]. The actual research trend is more focused on the development of bacterial and/or fungal multistrain consortia with the rationale that they could show additive or synergistic effects and perform better than single strains [39,40]. Mixed plant growth-promoting microorganism inoculants might adapt to a wider range of environmental conditions and could exert their effect through multiple modes of action [41,42]. Nevertheless, when mixing beneficial microbial strains, antagonistic interactions could arise and reduce the efficacy of the microbial consortium or modify the effect on different crops [41].

Microbial biostimulants have been applied to many vegetable crops to improve plant growth and stress tolerance $[38,43]$ but there is limited information on their application to vegetable transplant production. Therefore, this study aimed to evaluate the use of microbial biostimulants to increase salt tolerance of lettuce and tomato seedlings during nursery growth.

\section{Materials and Methods}

\subsection{Plant Materials and Transplant Production}

A nursery trial was carried out in a greenhouse situated at the Department of Agricultural, Food, and Forest Sciences (SAAF-University of Palermo, Italy) $\left(38^{\circ} 6^{\prime} 28^{\prime \prime} \mathrm{N}\right.$ $13^{\circ} 21^{\prime} 3^{\prime \prime} \mathrm{E}$; altitude $49 \mathrm{~m}$ above sea level) to evaluate the effects of salt stress and microbial biostimulant inoculation on transplant production.

During autumn 2020, seeds of Lactuca sativa L. "Meraviglia d'inverno" (Blumen, Piacenza, Italy) and Solanum lycopersicum L. "Marmande" (Vilmorin, La Ménitré, France) were sown into nine polystyrene trays for each species with 160 or 104 cells each for lettuce and tomato, respectively. Three trays were filled with a commercial substrate (Utilis, GreenView srl, Crocetta del Montello, Italy, fertilized with $850 \mathrm{~g} \mathrm{~m}^{-3}$ of a mineral fertilizer NPK), the other three trays were filled with the same substrate inoculated with $1.5 \mathrm{~g} \mathrm{~L}^{-1}$ of TNC Bactorr ${ }^{\mathrm{S} 13}$ (The Nutrient Company, Rochdale, UK), and the remaining trays were also filled with the commercial substrate inoculated with $0.75 \mathrm{~g} \mathrm{~L}^{-1}$ of Flortis Micorrize (Orvital, Settimo Milanese, Italy). Bactorr ${ }^{\mathrm{S13}}$ (B) and Flortis Micorrize (M) are commercial biostimulants: the first contains plant growth-promoting bacteria $\left(1.3 \times 10^{8} \mathrm{CFU} \mathrm{g}^{-1}\right.$ of Bacillus amyloliquefaciens, B. brevis, B. circulans, B. coagulans, B. firmus, B. halodenitrificans, B. laterosporus, B. licheniformis, B. megaterium, B. mycoides, B. pasteurii, B. subtilis, and Paenibacillus polymyxa) as well as soluble humates, natural plant hormones, amino acids, vitamins, and trace elements derived from Ascophylum nodosum; the second contains $30 \%$ of Glomus spp., $1.24 \times 10^{8} \mathrm{CFU} \mathrm{g}^{-1}$ of Agrobacterium radiobacter, Bacillus subtilis, Streptomyces spp. and $3 \times 10^{5} \mathrm{CFU} \mathrm{g}^{-1}$ of Thricoderma spp.

After sowing (October 2020), the trays were kept in a dark room at $22 \pm 1{ }^{\circ} \mathrm{C}$ and were transferred to the greenhouse for seedling growth when the first emergence was observed. Plantlet emergence occurred two and four days after sowing for lettuce and tomato, respectively. Three days after emergence, only one plantlet per cell was left.

During the trial, the average temperature outside the greenhouse was between $15.5 \pm 0.3{ }^{\circ} \mathrm{C}$ (night) and $23.0 \pm 0.3{ }^{\circ} \mathrm{C}$ (day), and the average net solar radiation at noon was $478 \mathrm{~W} \cdot \mathrm{m}^{-2}$, with a day length that ranged between 9 and $10 \mathrm{~h}$. The air temperature inside the greenhouse was on average $21.6 \pm 1.1^{\circ} \mathrm{C}$ and ranged between 35.2 (day) and $12.4{ }^{\circ} \mathrm{C}$ (night) (Figure 1), whereas the relative humidity was $74.0 \pm 1.1 \%$ and ranged between $22.5 \%$ and $100 \%$; the light intensity at noon was $41,839 \pm 3780$ lux and ranged from 64,660 to 6097 lux as a function of the cloudiness. 


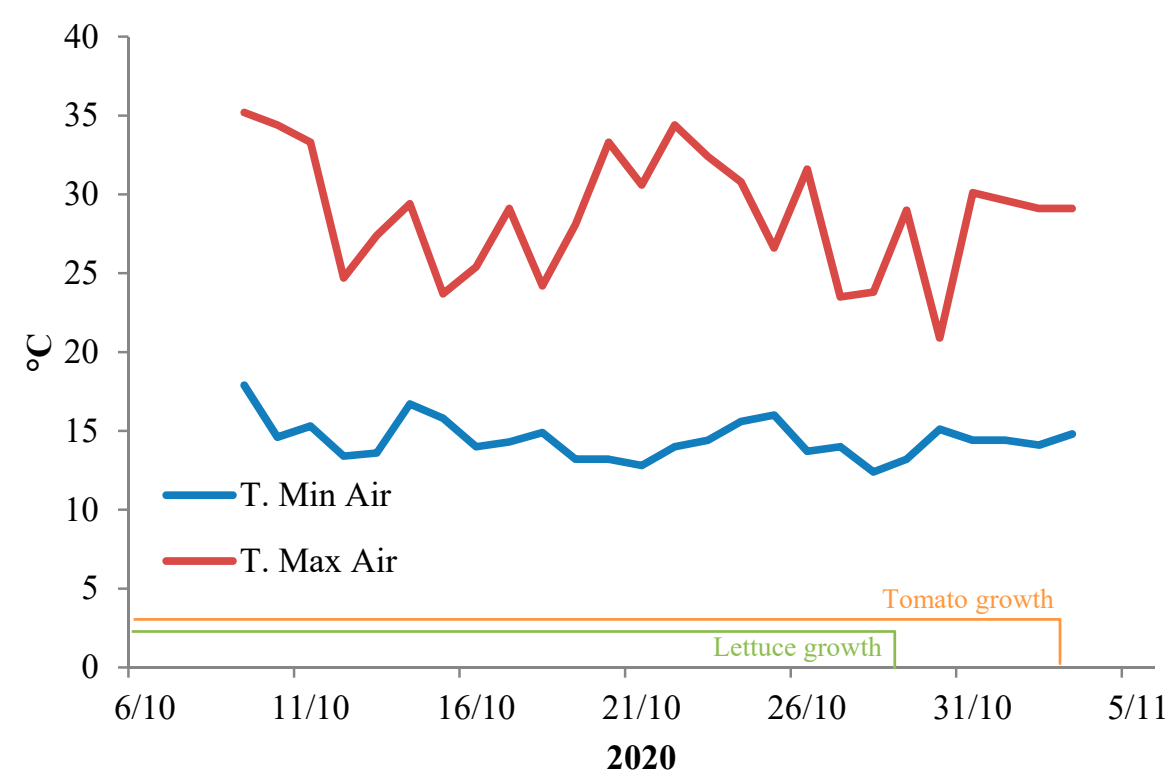

Figure 1. Daily average maximum and minimum temperatures of the air inside the greenhouse during nursery trials.

Salt treatments started when lettuce and tomato seedlings had the first true leaf (11th BBCH growth stage [44,45]) and were applied with an ebb and flow sub-irrigation system using water with $0 \mathrm{mM} \mathrm{NaCl}$ (Electrical conductivity-EC $0.68 \mathrm{dS} \mathrm{m}^{-1}$ ), $25 \mathrm{mM} \mathrm{NaCl}$ (EC 3.14

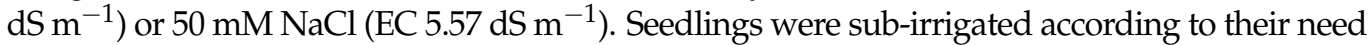
until they were ready for transplanting (twice a week on average) and sub-fertigated once a week with $3 \mathrm{~g} \mathrm{~L}^{-1}$ of a water-soluble NK fertilizer (13-46). The trays were weighed individually before each sub-irrigation and after the exceeding water was drained to measure the volume of water consumed during seedling growth and calculate the water use efficiency (WUE) and nitrogen use efficiency (NUE) as: WUE $\left(\mathrm{g} \mathrm{DW} \mathrm{L}{ }^{-1} \mathrm{H}_{2} \mathrm{O}\right)=$ plant dry weight $(\mathrm{g}) / \mathrm{H}_{2} \mathrm{O}(\mathrm{L})$; NUE $\left(\mathrm{g} \mathrm{DW} \mathrm{g}^{-1} \mathrm{~N}\right)=$ plant dry weight $(\mathrm{g}) /$ supplied $\mathrm{N}(\mathrm{g})$ (supplied $\mathrm{N}=$ initial $\mathrm{N}$ content of the substrate $+\mathrm{N}$ supplied with sub fertigation) [46].

One week before the end of the experiment (16 and 21 days after emergence for lettuce and tomato, respectively), leaf stomatal conductance was measured using a diffusion porometer (AP4, Delta-T Devices Ltd., Cambridge, UK) on two young unshaded leaves of 20 seedlings for each replicate of each combination biostimulants $\times$ salt stress. Conductance measurements were performed at the same hour and in similar conditions (substrate humidity, light intensity, air temperature, and humidity) for both species.

The seedlings were considered ready for transplanting when they had 4-5 true leaves (14-15th BBCH growth stage [44,45]) (23 and 28 days from sowing for lettuce and tomato, respectively). At that time, transplants were randomly selected (four replicated samples of 30 seedlings for each species and each treatment) and their morphological characteristics (seedling height, stem diameter, and leaf number) were evaluated.

Leaf color was measured on the upper part of two randomly selected leaves of each seedling with a colorimeter (CR-400, Minolta corporation, Ltd., Osaka, Japan) that recorded $L^{*}$ (lightness), $a^{*}$ (positive values for reddish colors and negative values for greenish colors), and $\mathrm{b}^{*}$ (positive values for yellowish colors and negative values for bluish colors). Hue angle $\left(\mathrm{h}^{\circ}\right)$ and Chroma $\left(\mathrm{C}^{*}\right)$ were calculated from $\mathrm{a}^{*}$ and $\mathrm{b}^{*}$ values as $\mathrm{h}^{\circ}=180^{\circ}+\arctan$ $\left(b^{*} / a^{*}\right)$ [47] and $C^{*}=\left(a^{* 2}+b^{* 2}\right)^{1 / 2}$. Soon after, leaves, stems, and roots were separately weighed and dried at $85^{\circ} \mathrm{C}$ to a constant weight to calculate the fresh and dry biomass and the shoot/root ratio for both fresh and dry weight. Before drying, the leaf area of each seedling was measured by scanning leaves at 350 dpi (Epson Perfection 4180 Photo, Seiko Epson Corp., Suwa, Japan) and analyzing with the ImageJ 1.52a software (National Institutes Health, Bethesda, MD, USA) the digital images obtained. Leaf area and leaf 
dry weight were used to calculate the specific leaf area $\left(\right.$ SLA $\left.\mathrm{cm}^{2} \mathrm{~g}^{-1} \mathrm{DW}\right)$ as SLA = leaf area/leaf dry weight.

At the end of the nursery trial, the water status of the seedlings of each species and each treatment was assessed by determining their relative water content (RWC). Ten leaves for each replicate were randomly sampled and their fresh weight was immediately measured; then, leaves were placed in distilled water for $4 \mathrm{~h}$ to measure their turgid weight (TW) before drying in an oven at $80^{\circ} \mathrm{C}$ for $24 \mathrm{~h}$. Dried leaves were weighed to measure their dry weight (DW) and finally, the relative water content was calculated as $\mathrm{RWC}=(\mathrm{FW}-\mathrm{DW}) /(\mathrm{TW}-\mathrm{DW}) \times 100$.

\subsection{Statistics and Principal Component Analysis}

The experimental design consisted of four replicated samples of 30 seedlings each for every combination of microbial biostimulant and $\mathrm{NaCl}$ level, randomly assigned in four blocks. A two-way ANOVA was used to analyze the effects of microbial biostimulants and $\mathrm{NaCl}$ levels on lettuce and tomato seedlings. The mean values of each parameter considered were compared by the least significant differences (LSD) test at $p \leq 0.05$ to discriminate the differences among treatments and the interactions between factors.

The morphophysiological parameters of lettuce and tomato seedlings were further analyzed through a principal component analysis to explore the main parameters that were most effective in discriminating between $\mathrm{NaCl}$ levels and microbial biostimulants. The input matrix for the analysis consisted of height, stem diameter, total, leaf, stem and root fresh and dry weight, shoot/root ratio of fresh and dry weights, dry matter percentage, WUE, RWC, leaf number, total leaf area, SLA, stomatal conductance, $\mathrm{L}^{*}$, Chroma, and Hue angle of lettuce and tomato seedlings. The number of principal components (PCs) was assessed by holding only the factors with eigenvalues higher than 1.0. The plot of the PCs was used to study the correlations between the variables of the input data set. Moreover, the initial 22 variables were projected into the subspace defined by the first and second PCs, and correlated variables were revealed.

\section{Results}

\subsection{Morphophysiological Parameters of Lettuce Seedlings}

Lettuce plantlets emerged two days after sowing (at least $50 \%$ of plantlets emerged) and seedlings were ready for transplanting (at least four true leaves; 14th BBCH growth stage [44]) after 23 days from sowing.

The height of lettuce seedlings was significantly affected by the experimental treatments. At the end of the trial, the control seedlings showed a reduction of plant height with increasing $\mathrm{NaCl}$ concentration from $9.0(0 \mathrm{mM} \mathrm{NaCl})$ to $6.2 \mathrm{~cm}(50 \mathrm{mM} \mathrm{NaCl})$. The seedlings inoculated with $\mathrm{B}$ had a height similar to the unstressed control seedlings irrespective of salt stress (from 9.4 to $8.6 \mathrm{~cm})$, whereas M-treated seedlings were the highest with $0 \mathrm{mM} \mathrm{NaCl}(11.5 \mathrm{~cm})$ and even if they suffered height reduction with both 25 and $50 \mathrm{mM} \mathrm{NaCl}(-15.9 \%$ and $-26.2 \%$, respectively), they did not significantly differ from the unstressed control seedlings (Table 1). The stem diameter was $2.8 \mathrm{~mm}$ on average in control seedlings and increased by $10.7 \%$ in the seedlings inoculated with the microbial biostimulants (Table 1). All the seedlings significantly lowered the diameter of their stem at each salinity level. 


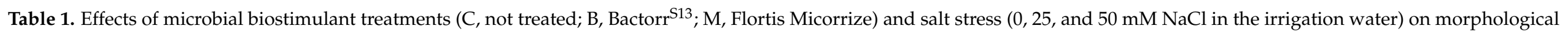
parameters of lettuce seedlings.

\begin{tabular}{|c|c|c|c|c|c|c|c|c|c|c|c|c|c|}
\hline \multirow{2}{*}{ Source of Variance } & \multirow{2}{*}{$\begin{array}{c}\text { Seedling } \\
\text { Height }(\mathrm{cm})\end{array}$} & \multirow{2}{*}{$\begin{array}{l}\text { StemDiameter } \\
(\mathrm{mm})\end{array}$} & \multicolumn{5}{|c|}{ Seedling Fresh Weight (g FW) } & \multicolumn{5}{|c|}{ Seedling Dry Weight (mg DW) } & \multirow{2}{*}{$\begin{array}{l}\text { Dry Matte } \\
\quad(\%)\end{array}$} \\
\hline & & & Total & Roots & Stem & Leaves & Shoot/Root & Total & Roots & Stem & Leaves & Shoot/Root & \\
\hline \multicolumn{14}{|l|}{ Treatment } \\
\hline $\mathrm{C}$ & z 7.5 & $2.8 \mathrm{~b}$ & $0.92 \mathrm{c}$ & 0.14 & $0.09 \mathrm{~b}$ & $0.69 c$ & 5.4 & $45.6 \mathrm{~b}$ & $8.2 b$ & $3.0 \mathrm{~b}$ & $34.3 b$ & 4.6 & 4.9 \\
\hline $\mathrm{B}$ & 9.0 & $3.1 \mathrm{a}$ & $1.28 \mathrm{~b}$ & 0.20 & $0.11 \mathrm{a}$ & $0.97 \mathrm{~b}$ & 5.7 & $65.9 \mathrm{a}$ & $12.2 \mathrm{a}$ & $3.8 \mathrm{a}$ & $49.8 \mathrm{a}$ & 4.5 & 5.0 \\
\hline $\mathrm{M}$ & 9.9 & $3.1 \mathrm{a}$ & $1.41 \mathrm{a}$ & 0.20 & $0.12 \mathrm{a}$ & $1.09 \mathrm{a}$ & 6.0 & $70.3 a$ & $12.9 \mathrm{a}$ & $4.2 \mathrm{a}$ & $53.3 a$ & 4.6 & 4.8 \\
\hline \multicolumn{14}{|l|}{$\mathrm{NaCl}(\mathrm{mM})$} \\
\hline 0 & 10.0 & $3.2 \mathrm{a}$ & $1.43 a$ & 0.22 & $0.12 \mathrm{a}$ & $1.10 \mathrm{a}$ & 5.7 & $69.3 a$ & $13.3 \mathrm{a}$ & 3.9 & $52.0 \mathrm{a}$ & 4.3 & 4.5 \\
\hline 25 & 8.7 & $3.0 \mathrm{~b}$ & $1.19 b$ & 0.17 & $0.12 \mathrm{a}$ & $0.90 \mathrm{~b}$ & 5.9 & $58.8 \mathrm{~b}$ & $10.0 \mathrm{~b}$ & 3.8 & $45.0 \mathrm{~b}$ & 4.9 & 4.8 \\
\hline 50 & 7.8 & $2.8 \mathrm{c}$ & $0.99 \mathrm{c}$ & 0.16 & $0.09 \mathrm{~b}$ & $0.75 c$ & 5.4 & $53.7 \mathrm{c}$ & $10.0 \mathrm{~b}$ & 3.3 & $40.4 c$ & 4.5 & 5.3 \\
\hline \multicolumn{14}{|l|}{ Treatment $\times \mathrm{NaCl}$} \\
\hline \multirow[t]{3}{*}{$\mathrm{C}$} & $9.0 \mathrm{bc}$ & 3.1 & 1.13 & $0.16 \mathrm{~d}$ & 0.10 & 0.87 & $5.9 \mathrm{ab}$ & 56.5 & 10.0 & 3.5 & 43.0 & 4.8 & $4.8 \mathrm{~b}$ \\
\hline & $7.3 \mathrm{~d}$ & 2.8 & 0.93 & 0.14 de & 0.09 & 0.70 & $5.5 \mathrm{ab}$ & 43.3 & 7.3 & 3.0 & 33.0 & 5.0 & $4.6 \mathrm{bc}$ \\
\hline & $6.2 \mathrm{e}$ & 2.6 & 0.69 & $0.12 \mathrm{e}$ & 0.07 & 0.50 & $4.7 \mathrm{~b}$ & 36.8 & 7.3 & 2.5 & 27.0 & 4.1 & $5.2 \mathrm{ab}$ \\
\hline \multirow[t]{3}{*}{ B } & $9.4 \mathrm{bc}$ & 3.3 & 1.43 & $0.23 b$ & 0.11 & 1.10 & $5.3 b$ & 72.8 & 14.0 & 4.3 & 54.5 & 4.2 & $4.5 \mathrm{bc}$ \\
\hline & $9.0 \mathrm{bc}$ & 3.2 & 1.28 & $0.19 c$ & 0.14 & 0.96 & $5.7 \mathrm{ab}$ & 66.0 & 12.0 & 4.3 & 49.8 & 4.5 & $5.0 \mathrm{ab}$ \\
\hline & $8.6 c$ & 2.9 & 1.14 & $0.17 \mathrm{~cd}$ & 0.10 & 0.87 & $6.0 \mathrm{ab}$ & 58.9 & 10.7 & 3.0 & 45.3 & 4.8 & $5.4 \mathrm{a}$ \\
\hline \multirow{3}{*}{$\begin{array}{c}50 \\
\text { Significance }^{\mathrm{x}}\end{array}$} & $11.5 \mathrm{a}$ & 3.2 & 1.73 & $0.26 a$ & 0.14 & 1.33 & $5.7 \mathrm{ab}$ & 78.5 & 16.0 & 4.0 & 58.5 & 4.0 & $4.2 \mathrm{c}$ \\
\hline & $9.7 \mathrm{~b}$ & 3.1 & 1.36 & $0.18 \mathrm{~cd}$ & 0.13 & 1.05 & $6.6 a$ & 66.9 & 10.7 & 4.0 & 52.3 & 5.3 & $4.8 \mathrm{~b}$ \\
\hline & \multicolumn{13}{|c|}{ Significance $^{\mathrm{x}}$} \\
\hline Treatment & $* * *$ & $* * *$ & $* * *$ & $* * *$ & $* *$ & $* * *$ & $*$ & $* * *$ & $* * *$ & * & $* * *$ & ns & ns \\
\hline $\mathrm{NaCl}$ & $* * *$ & $* * *$ & $* * *$ & $* * *$ & * & $* * *$ & ns & $* * *$ & $* * *$ & ns & $* * *$ & ns & $* * *$ \\
\hline Treatment $\times \mathrm{NaCl}$ & $* *$ & ns & ns & $* * *$ & ns & ns & $*$ & ns & ns & ns & ns & ns & $* *$ \\
\hline
\end{tabular}

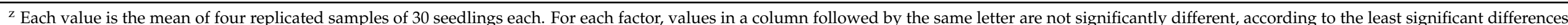
(LSD) test. ${ }^{\times}$Significance: $\mathrm{ns}=$ not significant; ${ }^{*}$ significant at $p<0.05$; ${ }^{* *}$ significant at $p<0.01$; ${ }^{* * *}$ significant at $p<0.001$. 
All the treatments recorded a linear decrease in the seedling total fresh weight when salt stress increased, but the inoculation of the substrate with the microbial biostimulants (especially M) raised the fresh biomass accumulation above the values of unstressed control seedling (Table 1, Figure 2a). The biostimulant treatments had a great effect on the fresh weight of the roots. The hypogeal part of control seedlings accumulated less fresh biomass and ranged from 0.16 to $0.12 \mathrm{~g} \mathrm{FW}$ seedling $^{-1}$ for 0 and $50 \mathrm{mM}$, respectively. The root fresh weight of non-stressed B-treated and M-treated seedlings increased by $39.3 \%$ and $57.7 \%$, respectively, compared to control. The seedlings grown on inoculated substrate lowered the fresh weight of their roots with $25 \mathrm{mM} \mathrm{NaCl}$ with no further decrease with $50 \mathrm{mM} \mathrm{NaCl}$ ( $0.18 \mathrm{~g} \mathrm{FW}$ seedling $^{-1}$ on average) (Table 1, Figure $\left.2 \mathrm{a}\right)$. As reported for stem diameter, stem fresh weight was positively influenced by the microbial biostimulants but was negatively influenced only by the highest salinity level (Table 1, Figure 2a). Leaves represented the main part of the seedlings and their fresh weight recorded variations superimposable with those found for the total fresh weight. The hypogeal and epigeic parts of the seedling were similarly influenced by the treatments so that only small variations were recorded in the fresh weight shoot/root ratio due to the combination of the experimental factors (Table 1).
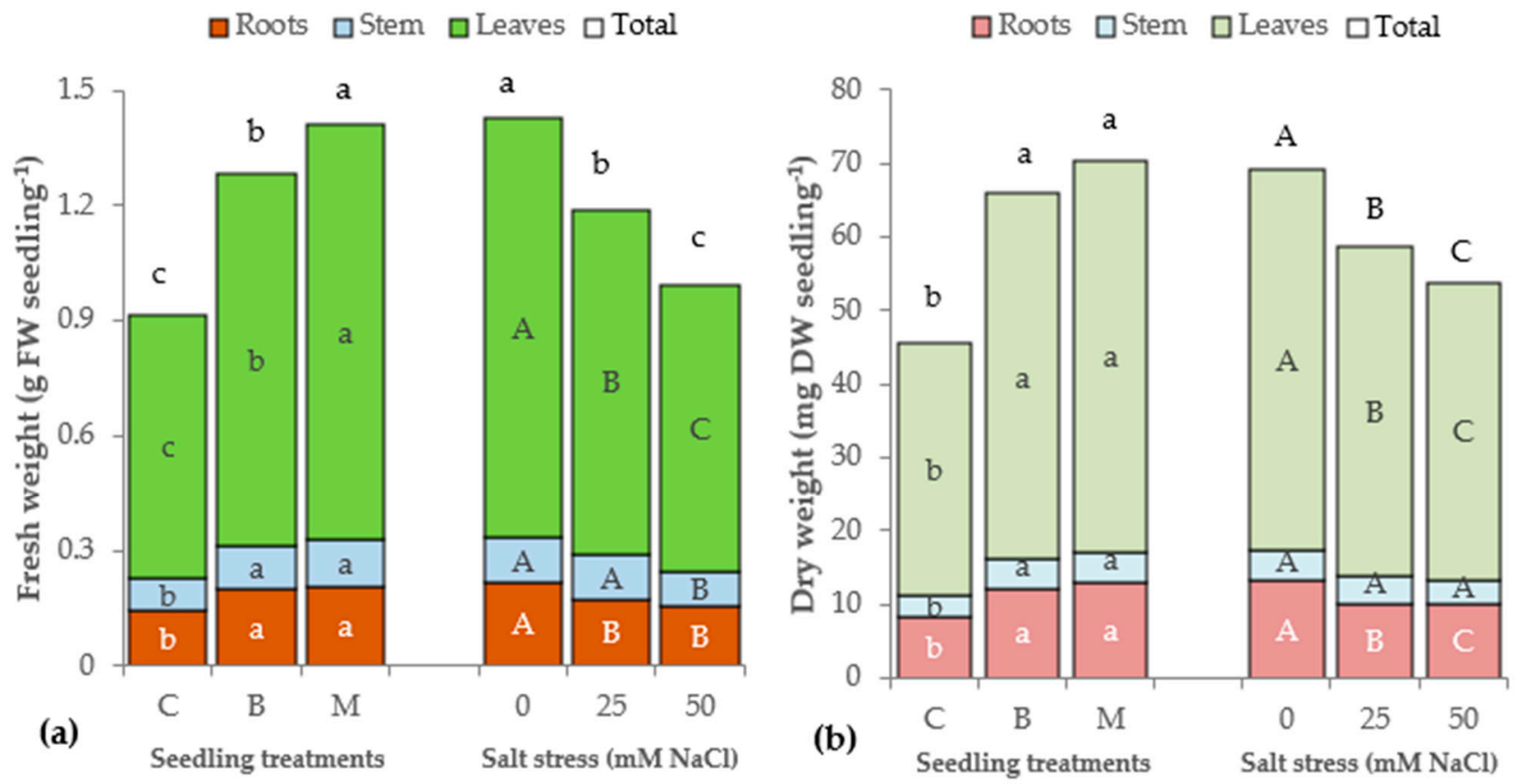

Figure 2. Effect of microbial biostimulant treatments (C, untreated control; B, Bactorr ${ }^{\mathrm{S} 13}$; M, Flortis Micorrize) and salt stress $(0,25$, and $50 \mathrm{mM} \mathrm{NaCl}$ in the irrigation water) on the total, root, stem, and leaf (a) fresh and (b) dry weight of lettuce seedlings (bars of the same color with different uppercase or lowercase letters are significantly different at $p<0.05$ according to the LSD test).

The accumulation of dry biomass of lettuce seedlings was positively affected by the microbial biostimulant, but all the treatments suffered dry weight reductions due to salt stress (Table 1, Figure 2b). The seedlings inoculated with Bactorr $\mathrm{S}^{13}$ (B) and Flortis Micorrize (M) had an average total dry weight higher than control (45.6 mg DW seedling $\left.{ }^{-1}\right)$ by 44.6 and $54.3 \%$, respectively. Salinity determined a linear decrease of the total dry biomass from 69.3 to $53.7 \mathrm{mg} \mathrm{DW} \mathrm{seedling}^{-1}$ on average for 0 and $50 \mathrm{mM} \mathrm{NaCl}$ with significant drops at each salinity level. All the seedling parts (roots, stem, and leaves) had a higher dry biomass accumulation when treated with the microbial biostimulants. The root dry weight was significantly reduced with the intermediate salinity level with no further decrease at $50 \mathrm{mM} \mathrm{NaCl}(-25.0 \%$ on average), whereas the leaf dry weight recorded an additional reduction at the highest salinity level (-13.5 and $-22.3 \%$ with 25 and $50 \mathrm{mM}$ $\mathrm{NaCl}$, respectively). Despite the water salinity negatively affected all the seedlings, the 
increased dry biomass accumulation recorded in the inoculated seedlings compared to control seedlings allowed to counteract salt stress; B and M seedlings grown with $50 \mathrm{mM}$ $\mathrm{NaCl}$ recorded values of dry biomass in the different seedling parts similar or even higher than unstressed control seedlings $(+6.0 \%$ and $+17.0 \%$ on average for roots and leaves of $B$ seedlings and $\mathrm{M}$ seedlings, respectively). No modification was recorded in dry biomass partitioning due to the experimental factors as shown by the small changes of the dry weight $S / R$ ratio. The dry matter percentage of seedling shoot increased when salt stress increased. Control seedlings ranged from $4.8 \%$ to $5.2 \%$ with no significant difference, while the variation recorded was greater and statistically significant for B seedlings (from $4.5 \%$ to $5.4 \%$ ) and even more for M seedlings (from $4.2 \%$ to $5.5 \%$ ) (Table 1 ).

The water use efficiency (WUE) was significantly affected by salt stress in control seedlings that accumulated $2.7 \mathrm{~g} \mathrm{DW} \mathrm{L}{ }^{-1} \mathrm{H}_{2} \mathrm{O}$ with $0 \mathrm{mM} \mathrm{NaCl}$ and lowered this value down to $1.6 \mathrm{~g} \mathrm{DW} \mathrm{L}^{-1} \mathrm{H}_{2} \mathrm{O}$ with $50 \mathrm{mM} \mathrm{NaCl}$ (Table 1, Figure 3a). The seedlings inoculated with $\mathrm{B}$ or $\mathrm{M}$ recorded $3.0 \mathrm{~g}$ DW L ${ }^{-1} \mathrm{H}_{2} \mathrm{O}$ with $0 \mathrm{mM} \mathrm{NaCl}$ and were not significantly affected by salt stress. The nitrogen use efficiency (NUE) varied significantly as a function of seedling treatments and salt stress. The uninoculated seedlings showed the lowest NUE (3.5 g DW g ${ }^{-1} \mathrm{~N}$, on average) whereas a significantly higher NUE was recorded in the inoculated seedlings (5.1 and $5.4 \mathrm{~g} \mathrm{DW} \mathrm{g}^{-1} \mathrm{~N}$ with $\mathrm{B}$ and $\mathrm{M}$, respectively). All the seedling treatments recorded a descending trend of NUE when increasing the salt stress that reduced the NUE from $5.3 \mathrm{~g} \mathrm{DW} \mathrm{g}^{-1} \mathrm{~N}$ in the unstressed seedlings to $4.1 \mathrm{~g} \mathrm{DW} \mathrm{g}^{-1} \mathrm{~N}$ in the seedlings irrigated with the highest irrigation water salinity (Figure $3 b$ ).
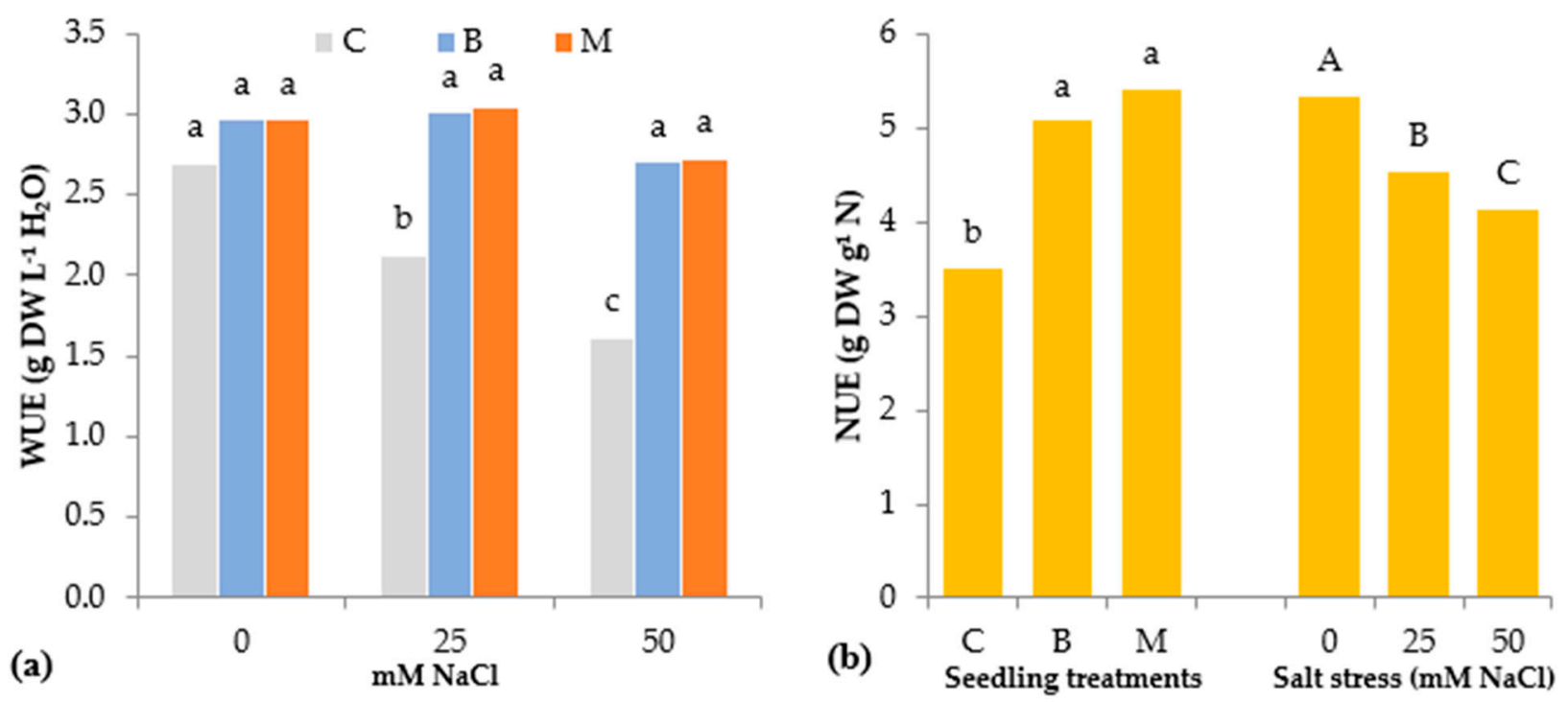

Figure 3. Effect of the seedling treatments (C, not treated; B, Bactor ${ }^{\mathrm{S} 13}$; M, Micorrize) and salt stress $(0,25$, and $50 \mathrm{mM} \mathrm{NaCl}$ in the irrigation water) on (a) the water use efficiency (WUE) and (b) the nitrogen use efficiency (NUE) of lettuce seedlings (bars with different uppercase or lowercase letters are significantly different at $p<0.05$ according to the LSD test).

The lettuce seedlings inoculated with Bactorr ${ }^{\mathrm{S} 13}$ had more leaves (5.6 leaves seedling ${ }^{-1}$ ) than the untreated and M-treated seedlings (5.1 and 5.3 leaves seedling ${ }^{-1}$, respectively) (Table 2). All the seedlings recorded a negative effect of salt stress on the leaf number that resulted significantly lower with $50 \mathrm{mM} \mathrm{NaCl}$. Leaf area showed to be affected differently by salt stress according to substrate inoculation (Table 2). The unstressed control seedlings had an average leaf area of $7.8 \mathrm{~cm}^{2} \mathrm{leaf}^{-1}$ and a total leaf area of $41.4 \mathrm{~cm}^{2}$ seedling ${ }^{-1}$. These values dropped significantly with $25 \mathrm{mM} \mathrm{NaCl}(-24.2 \%$ and $-27.7 \%$, respectively) with no further reduction at the highest salinity level. The unstressed seedlings inoculated with $\mathrm{M}$ had the largest leaves $\left(11.4 \mathrm{~cm}^{2}\right.$ leaf $\left.^{-1}\right)$ and the greatest total leaf area $\left(61.8 \mathrm{~cm}^{2}\right.$ seedlings ${ }^{-1}$ ). M-treated seedlings also suffered the negative effects of salt stress but counteracted salinity up to $50 \mathrm{mM} \mathrm{NaCl}$ ending with slightly higher values of leaf area than 
unstressed control seedlings (+19.2\% with $25 \mathrm{mM} \mathrm{NaCl}$ and $+7 \%$ with $50 \mathrm{mM} \mathrm{NaCl}$ than total leaf area of control seedlings with $0 \mathrm{mM} \mathrm{NaCl}$ ). The other microbial biostimulant (B) was less effective in promoting leaf area expansion without salt stress than $M$ but resulted in a significant increase of total leaf area against control seedlings due to the higher leaf number per seedling. The B-treated seedlings grown under salinity conditions recorded a higher leaf area than control (+11.9\% with $25 \mathrm{mM} \mathrm{NaCl}$ and $+1 \%$ with $50 \mathrm{mM} \mathrm{NaCl}$ than total leaf area of control seedlings with $0 \mathrm{mM} \mathrm{NaCl}$ ) and did not differ statistically from M-treated seedlings.

Table 2. Effects of microbial biostimulant treatment (C, not treated; B, Bactorr ${ }^{\mathrm{S} 13}$; M, Flortis Micorrize) and salt stress (0, 25, and $50 \mathrm{mM} \mathrm{NaCl}$ in the irrigation water) on the leaf characteristics of lettuce seedlings.

\begin{tabular}{|c|c|c|c|c|c|c|c|c|c|c|}
\hline \multirow{2}{*}{\multicolumn{2}{|c|}{$\begin{array}{l}\begin{array}{l}\text { Source of } \\
\text { Variance }\end{array} \\
\text { Treatment }\end{array}$}} & \multirow[t]{2}{*}{$\begin{array}{l}\text { Number } \\
\text { of } \\
\text { Leaves }\end{array}$} & \multirow[t]{2}{*}{$\begin{array}{l}\text { Leaf Area } \\
\quad\left(\mathrm{cm}^{2}\right. \\
\left.\text { Seedling }^{-1}\right)\end{array}$} & \multirow[t]{2}{*}{$\begin{array}{c}\text { Leaf Area } \\
\left(\mathrm{cm}^{2} \text { Leaf }^{-1}\right)\end{array}$} & \multirow[t]{2}{*}{$\begin{array}{l}\operatorname{SLA}^{y} \\
\left(\mathrm{~cm}^{2} \mathrm{~g}\right. \\
\left.\mathrm{DW}^{-1}\right)\end{array}$} & \multirow[t]{2}{*}{$\begin{array}{c}\text { Stomatal } \\
\text { Conduc- } \\
\text { tance }(\mathrm{mmol} \\
\left.\mathrm{m}^{2} \mathrm{~s}^{-1}\right)\end{array}$} & \multirow[t]{2}{*}{$\begin{array}{c}\text { RWC } \\
(\%)\end{array}$} & \multirow[t]{2}{*}{$\mathbf{L}$} & \multicolumn{2}{|c|}{ Chroma Hue $^{\circ}$} \\
\hline & & & & & & & & & & \\
\hline & & z $5.1 b$ & 31.9 & 6.3 & 926.4 & 360.0 & $94.1 \mathrm{~b}$ & 52.6 & 41.9 & 121.6 \\
\hline & & $5.6 \mathrm{a}$ & 46.1 & 8.2 & 928.1 & 365.1 & $95.8 \mathrm{ab}$ & 52.2 & 41.8 & 122.2 \\
\hline & & $5.3 b$ & 51.8 & 9.8 & 970.7 & 358.3 & $96.5 a$ & 51.9 & 41.8 & 122.1 \\
\hline \multicolumn{11}{|c|}{$\mathrm{NaCl}(\mathrm{mM})$} \\
\hline & & $5.5 \mathrm{a}$ & 51.2 & 9.3 & 982.0 & 532.9 & $96.9 a$ & 52.7 & 42.6 & 121.5 \\
\hline & & $5.3 \mathrm{ab}$ & 41.9 & 7.9 & 929.6 & 330.9 & $95.8 \mathrm{a}$ & 52.5 & 41.8 & 122.0 \\
\hline & & $5.2 \mathrm{~b}$ & 36.9 & 7.1 & 913.6 & 219.7 & $93.8 \mathrm{~b}$ & 51.5 & 41.1 & 122.3 \\
\hline \multicolumn{11}{|c|}{ Treatment $\times \mathrm{NaCl}$} \\
\hline \multirow[t]{3}{*}{$\mathrm{C}$} & 0 & 5.3 & $41.4 \mathrm{c}$ & $7.8 \mathrm{c}$ & $963.2 b$ & $563.3 a$ & 95.3 & $52.4 \mathrm{ab}$ & $41.9 \mathrm{ab}$ & $121.6 \mathrm{ab}$ \\
\hline & 25 & 5.1 & $29.9 d$ & $5.9 \mathrm{~d}$ & $906.8 \mathrm{c}$ & $245.1 c$ & 94.5 & $53.0 \mathrm{a}$ & $41.8 \mathrm{ab}$ & $121.8 \mathrm{ab}$ \\
\hline & 50 & 4.8 & $24.5 \mathrm{~d}$ & $5.1 \mathrm{~d}$ & $909.2 \mathrm{c}$ & $271.7 \mathrm{c}$ & 92.6 & $52.5 \mathrm{ab}$ & $42.0 \mathrm{a}$ & $121.2 b$ \\
\hline \multirow[t]{3}{*}{ B } & 0 & 5.8 & $50.3 b$ & $8.6 b c$ & $926.4 \mathrm{bc}$ & $526.9 a$ & 97.3 & $52.6 \mathrm{ab}$ & $43.1 \mathrm{a}$ & $121.6 \mathrm{ab}$ \\
\hline & 25 & 5.6 & $46.3 \mathrm{bc}$ & $8.3 c$ & $931.5 b c$ & $384.3 b$ & 95.9 & $53.2 \mathrm{a}$ & $42.3 \mathrm{a}$ & $122.1 \mathrm{ab}$ \\
\hline & 50 & 5.5 & $41.8 \mathrm{c}$ & $7.6 \mathrm{c}$ & $926.5 b c$ & $184.2 \mathrm{c}$ & 94.1 & $50.7 \mathrm{~b}$ & $40.1 b$ & $122.8 \mathrm{a}$ \\
\hline \multirow[t]{3}{*}{ M } & 0 & 5.4 & $61.8 \mathrm{a}$ & $11.4 \mathrm{a}$ & $1056.4 \mathrm{a}$ & $508.5 \mathrm{a}$ & 98.0 & $53.2 \mathrm{a}$ & $43.0 \mathrm{a}$ & $121.4 \mathrm{~b}$ \\
\hline & 25 & 5.3 & $49.4 \mathrm{~b}$ & $9.4 b$ & $950.7 \mathrm{bc}$ & $363.3 b$ & 96.9 & $51.2 \mathrm{ab}$ & $41.4 \mathrm{a}$ & $122.2 \mathrm{ab}$ \\
\hline & 50 & 5.2 & $44.3 \mathrm{bc}$ & $8.5 b c$ & $905.1 c$ & $203.2 \mathrm{c}$ & 94.5 & $51.4 \mathrm{ab}$ & $41.0 \mathrm{ab}$ & $122.8 \mathrm{ab}$ \\
\hline \multicolumn{11}{|c|}{ Significance $^{\mathrm{x}}$} \\
\hline & & $* * *$ & $* * *$ & $* * *$ & * & ns & $*$ & ns & ns & * \\
\hline & & * & $* * *$ & $* * *$ & $* *$ & $* * *$ & $* *$ & * & $* * *$ & * \\
\hline Treatı & $\mathrm{NaCl}$ & ns & $*$ & $* *$ & * & $* *$ & ns & * & $* *$ & * \\
\hline
\end{tabular}

${ }^{\mathrm{z}}$ Each value is the mean of four replicated samples of 30 seedlings each. For each factor, values in a column followed by the same letter are not significantly different, according to the LSD test. ${ }^{x}$ Significance: $\mathrm{ns}=$ not significant; ${ }^{*}$ significant at $p<0.05 ;{ }^{* *}$ significant at $p<0.01 ;{ }^{* * *}$ significant at $p<0.001$; y Specific leaf area.

The specific leaf area (SLA) showed a significant decrease due to salt stress in control seedlings $\left(963.2 \mathrm{~cm}^{2} \mathrm{~g}^{-1} \mathrm{DW}\right.$ with $0 \mathrm{mM} \mathrm{NaCl}$ and $908.0 \mathrm{~cm}^{2} \mathrm{~g}^{-1} \mathrm{DW}$ on average with 25 or $50 \mathrm{mM} \mathrm{NaCl}$ ). The B-treated seedlings showed no significant differences in SLA compared to control seedlings, while M-treated seedlings recorded the highest SLA under no stress $\left(1056.4 \mathrm{~cm}^{2} \mathrm{~g}^{-1} \mathrm{DW}\right)$ but had no significant difference compared to control seedlings under salt stress (Table 2).

The stomatal conductance of control seedlings ranged from $563.3 \mathrm{mmol} \mathrm{m}^{2} \mathrm{~s}^{-1}$ with $0 \mathrm{mM} \mathrm{NaCl}$ to $258.4 \mathrm{mmol} \mathrm{m}^{2} \mathrm{~s}^{-1}$ on average for 25 and $50 \mathrm{mM} \mathrm{NaCl}$. The seedlings treated with both microbial biostimulants did not record significant differences in stomatal conductance compared to control with 0 or $50 \mathrm{mM} \mathrm{NaCl}$ but significantly increased this parameter with the intermediate salinity level (Table 2).

The relative water content (RWC) of unstressed lettuce seedlings was on average $94.1 \%$ and was significantly lower than M-treated seedlings (96.5\%) (Table 2). All the seedlings recorded a reduction of the RWC due to salt stress, but their RWC resulted significantly lower only at the highest salinity level (Table 2). 
Leaf color can reveal the health status of the seedlings (Table 2). The modifications of lettuce leaf color due to the experimental treatments were very small and no significant difference was recorded among control seedlings and treated seedlings. Leaf color lightness ranged from 53.2 to 50.7. A significant reduction of leaf color vividness (Chroma) was found only in B-treated seedlings watered with the highest water salinity level. The Hue angle values ranged from $121.2^{\circ}$ to $122.8^{\circ}$.

\subsection{Morphophysiological Parameters of Tomato Seedlings}

Tomato plantlets emerged four days after sowing and seedlings were ready for transplanting (4-5 true leaves; 14-15th BBCH growth stage [45]) after $28 \mathrm{~d}$ from sowing.

The height of tomato seedlings was significantly affected only by the salt stress. It linearly dropped from $21.0 \mathrm{~cm}$ to $15.3 \mathrm{~cm}$ as salt stress increased (Table 3). Similar to seedling height, the stem diameter was affected only by salt stress, but tomato seedlings had a significantly lower stem diameter only with the highest salinity level (Table 3).

The fresh biomass of tomato seedlings was affected differently by salt stress according to the microbial biostimulant treatment (Table 3, Figure 4a). Seedling total fresh weight (FW) was $2.73 \mathrm{~g}$ in the unstressed control seedlings and was reduced significantly $(-24.8 \%)$ with $50 \mathrm{mM} \mathrm{NaCl}$. The seedlings inoculated with Bactorr ${ }^{\mathrm{S} 13}$ (B) and Flortis Micorrize (M) had a higher total fresh weight than control seedlings under non-saline conditions (3.11 and $2.96 \mathrm{~g}$, respectively). Under moderate and high salt stress, B-seedlings exhibited a reduction of total fresh biomass close to the values recorded in control seedlings under the same saline conditions (2.66 and $2.13 \mathrm{~g}$ with 25 and $50 \mathrm{mM} \mathrm{NaCl}$, respectively). M-treated seedlings did not suffer a significant reduction of total fresh weight with $25 \mathrm{mM} \mathrm{NaCl}(2.86 \mathrm{~g})$ resulting in a significantly higher fresh weight than that of control seedlings grown under the same salinity level $(+12.9 \%)$. The lower root fresh weight was recorded in control seedlings and the hypogeal part of the seedling was significantly increased by Flortis Micorizze $(+8.8 \%)$. All the seedlings suffered a reduction of root fresh weight under the highest salt stress, irrespective of the biostimulant treatment (Table 3, Figure 4a). More than half of the fresh biomass of the seedlings was accumulated in the stem, thus, the modifications of stem fresh weight were similar to those reported for the total fresh weight. The fresh weight of the leaves of the seedlings grown under non-saline conditions was higher in those inoculated with B $(1.05 \mathrm{~g})$ than those of $\mathrm{M}$ treatment $(0.97 \mathrm{~g})$ and control $(0.89 \mathrm{~g})$. The highest salinity level reduced leaf fresh weight down to $0.78 \mathrm{~g}$ on average in all the treatment, whereas the seedling inoculated with the microbial biostimulants had a significantly higher leaf fresh biomass than control under the intermediate salinity level ( $0.96 \mathrm{~g}$ on average for $\mathrm{B}$ and $\mathrm{M}$, $+17.4 \%$ than control). The differences in the response of the seedlings to the experimental treatments for root and shoot fresh biomass accumulation resulted in some changes in the biomass partitioning mainly due to salt stress that caused a linear reduction of $S / R$ from 8.1 to 6.1 for 0 and $50 \mathrm{mM} \mathrm{NaCl}$, respectively (Table 3). 


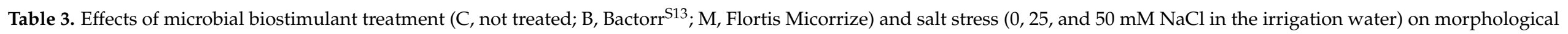
parameters of tomato seedlings.

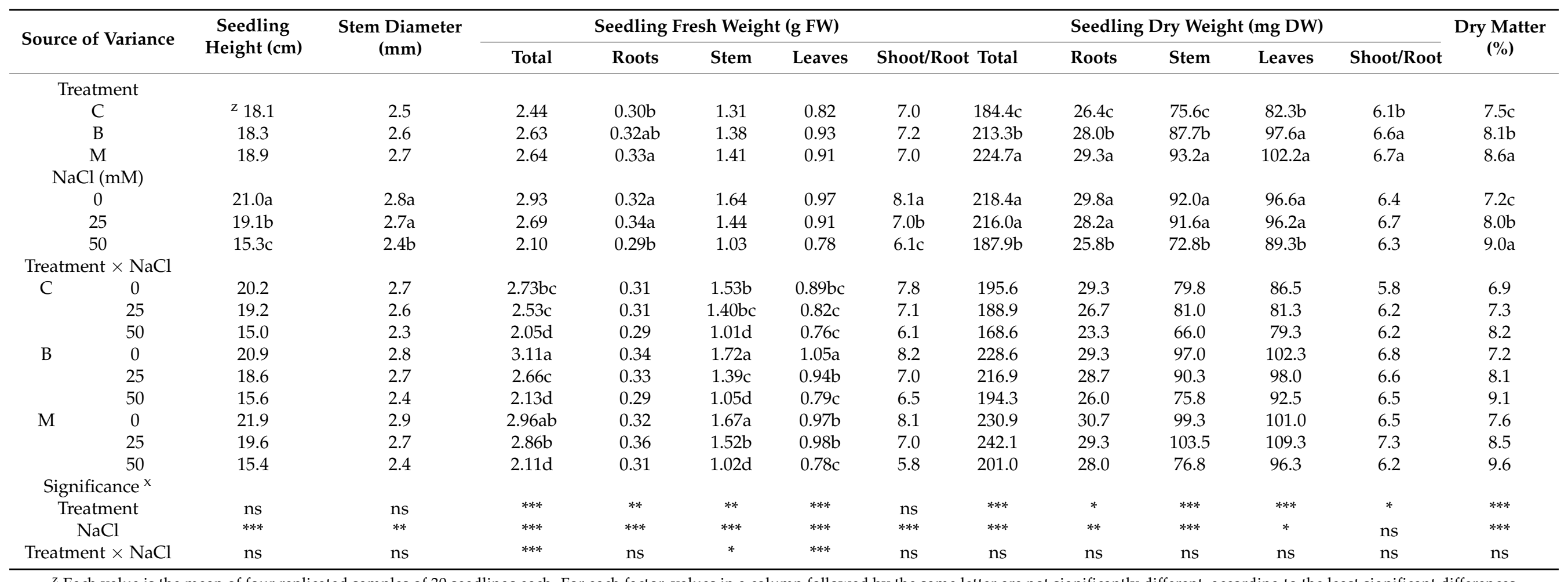

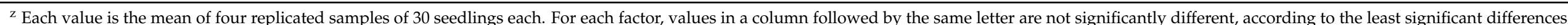

(LSD) test. ${ }^{\times}$Significance: $\mathrm{ns}=$ not significant; ${ }^{*}$ significant at $p<0.05$; ${ }^{* *}$ significant at $p<0.01$; ${ }^{* * *}$ significant at $p<0.001$. 

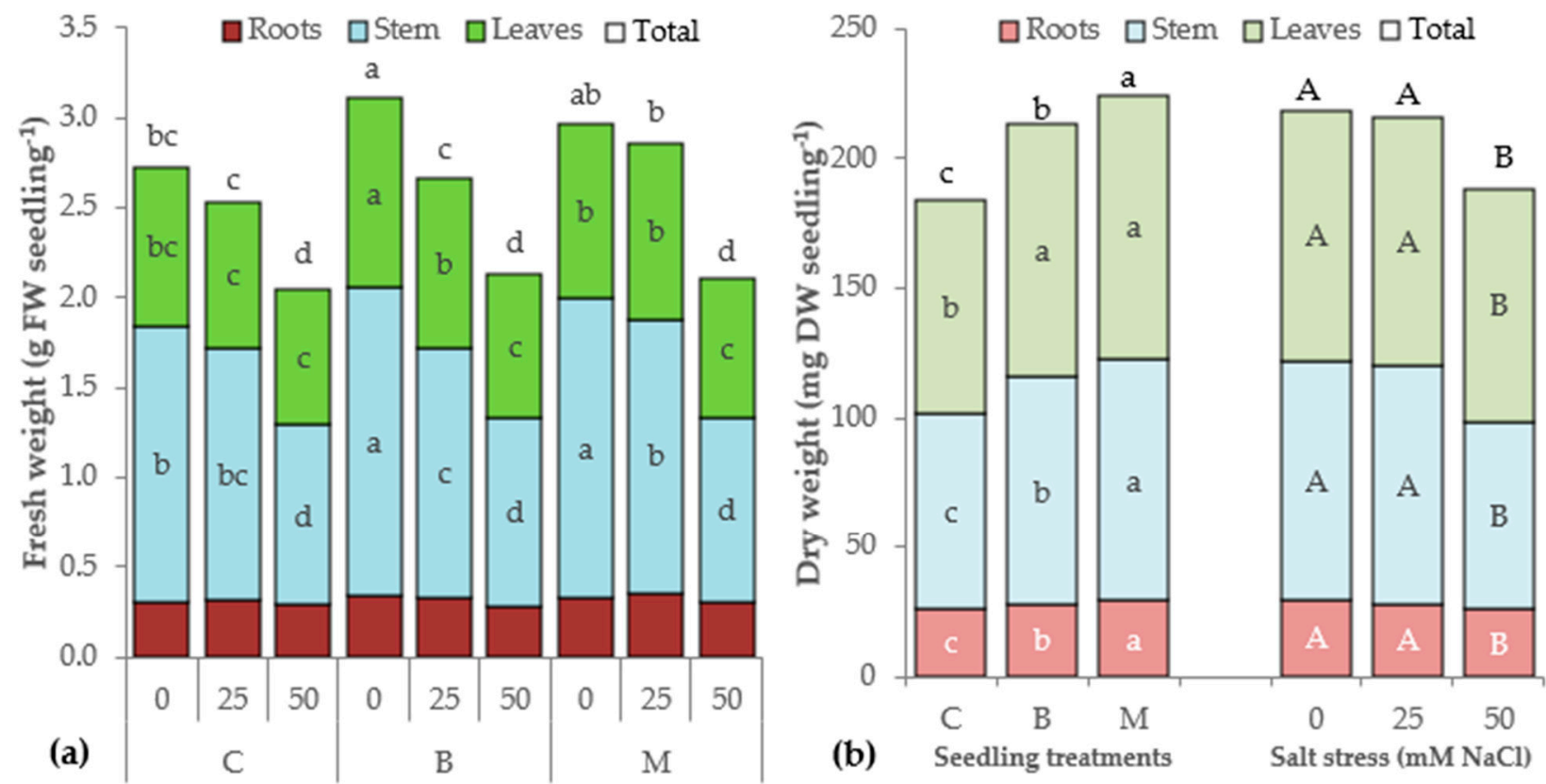

Figure 4. Effect of microbial biostimulant treatments (C, untreated control; B, Bactorr ${ }^{\mathrm{S} 13}$; $\mathrm{M}$, Flortis Micorrize) and salt stress $(0,25$, and $50 \mathrm{mM} \mathrm{NaCl}$ in the irrigation water) on the total, root, stem, and leaf (a) fresh or (b) dry weight of tomato seedlings (bars of the same color with different uppercase or lowercase letters are significantly different at $p<0.05$ according to the LSD test).

The dry weight (DW) of the seedlings and all the seedling parts (roots, stem, and leaves) was negatively affected by salt stress only at the highest salinity level irrespective of biostimulant treatments. The microbial inoculants were effective in increasing total dry biomass accumulation. The B-treated seedlings had on average $15.7 \%$ more total dry biomass than control whereas the M-treated seedlings accumulated significantly more dry biomass than B-treated seedlings and recorded $21.9 \%$ more dry biomass than control. The same differences were recorded also for root and stem dry weight while the leaf dry weight of the seedlings inoculated with $\mathrm{B}$ and $\mathrm{M}$ showed no differences among them and was significantly higher than control $(+21.3 \%$ on average) (Table 3 , Figure $4 \mathrm{~b})$. The dry biomass partitioning was influenced only by the microbial biostimulants that caused a significant increase of the shoot/root ratio compared to control seedlings (Table 3 ). The dry matter percentage was $7.5 \%$ in control seedlings; it raised to $8.1 \%$ in the seedlings inoculated with $\mathrm{B}$ and even more inoculating the substrate with $\mathrm{M}(8.6 \%)$ (Table 3$)$.

The water use efficiency (WUE) was not affected by salt stress in control seedlings that accumulated $3.5 \mathrm{~g} \mathrm{DW} \mathrm{L}{ }^{-1} \mathrm{H}_{2} \mathrm{O}$. The seedling inoculated with $\mathrm{B}$ had a higher WUE than control with 0 and $25 \mathrm{mM} \mathrm{NaCl}$. The seedling inoculated with $\mathrm{M}$ showed the highest WUE with $25 \mathrm{mM} \mathrm{NaCl}\left(4.6 \mathrm{~g}^{\mathrm{DW} \mathrm{L}}{ }^{-1} \mathrm{H}_{2} \mathrm{O}\right.$ ) and had a higher WUE than the control also with $50 \mathrm{mM} \mathrm{NaCl}$ (Figure 5a). The nitrogen use efficiency (NUE) varied significantly as a function of seedling treatments and salt stress. The uninoculated seedlings showed the lowest NUE (21.3 $\mathrm{g} \mathrm{DW} \mathrm{g}^{-1} \mathrm{~N}$, on average) whereas a significant increase of NUE was found in the inoculated seedlings that ranged from 24.7 to $26.0 \mathrm{~g} \mathrm{DW} \mathrm{g}^{-1} \mathrm{~N}$ with $\mathrm{B}$ and $\mathrm{M}$, respectively. All the seedling treatments recorded a significant decrease of NUE only when irrigated with the highest salinity level that reduced the NUE by $13.9 \%$ on average compared to the unstressed seedlings ( $25.3 \mathrm{~g} \mathrm{DW} \mathrm{g}^{-1} \mathrm{~N}$, on average) (Figure $5 \mathrm{~b}$ ). 

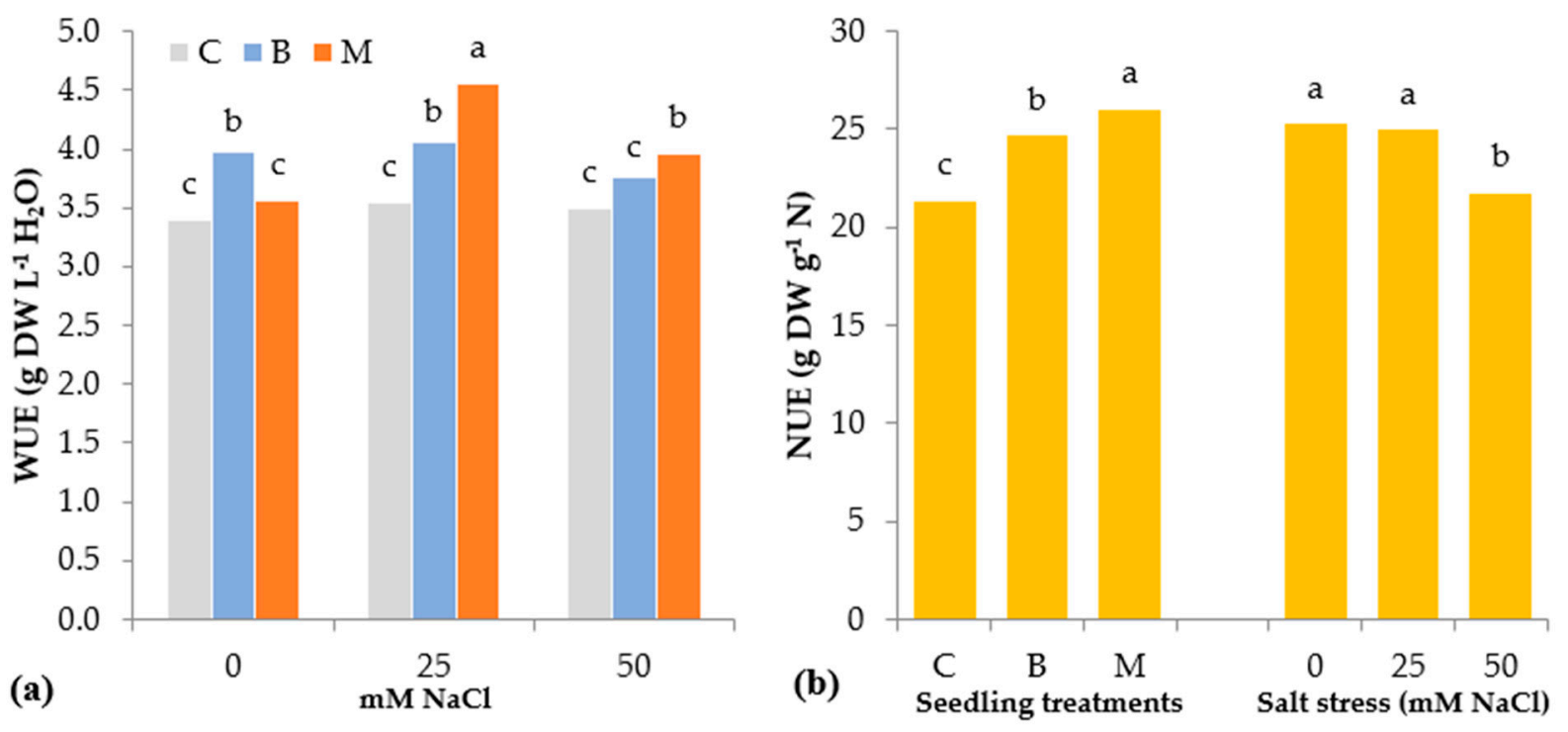

Figure 5. Effect of the seedling treatments (C, not treated; B, Bactorr ${ }^{S 13}$; M, Flortis Micorrize) and salt stress (0, 25, and 50 $\mathrm{mM} \mathrm{NaCl}$ in the irrigation water) on (a) the water use efficiency (WUE) and (b) the nitrogen use efficiency (NUE) of tomato seedlings (bars with different uppercase or lowercase letters are significantly different at $p<0.05$ according to the LSD test).

The tomato seedlings inoculated with microbial biostimulants recorded the highest leaf number (5.2 and 5.1 leaves seedling ${ }^{-1}$ for $B$ and $M$, respectively) (Table 4 ). The number of leaves significantly decreased only at the highest concentration of $\mathrm{NaCl}$ in the irrigation water $(-5.5 \%$ with $50 \mathrm{mM} \mathrm{NaCl}$ than control). The mean leaf area was significantly wider in M-treated seedlings $\left(9.9 \mathrm{~cm}^{2}\right.$ leaf $\left.{ }^{-1}\right)$ than control $\left(9.1 \mathrm{~cm}^{2}\right.$ leaf $\left.{ }^{-1}\right)$ on average. Salt stress reduced mean leaf size only with $50 \mathrm{mM} \mathrm{NaCl}$ in the irrigation water. Considering the total leaf area, tomato seedlings were positively affected by the microbial biostimulants (55.9 and $54.2 \mathrm{~cm}^{2}$ seedling ${ }^{-1}$ for $\mathrm{B}$ and $\mathrm{M}$, respectively, $+14.8 \%$ on average than control). With 25 and $50 \mathrm{mM} \mathrm{NaCl}$, the control seedlings recorded 46.1 and $39.4 \mathrm{~cm}^{2}$ seedling ${ }^{-1}$, respectively, and did not differ significantly from B-treated seedlings whereas M-treated seedlings were not affected by the moderate salt stress $\left(54.4 \mathrm{~cm}^{2}\right.$ seedling $\left.{ }^{-1}\right)$ and reduced their total leaf area only with $50 \mathrm{mM} \mathrm{NaCl}\left(42.6 \mathrm{~cm}^{2}\right.$ seedling $\left.{ }^{-1}\right)$ (Table 4).

Leaf thickness and dry biomass distribution in the leaves can be revealed by the specific leaf area (SLA) (Table 4). This parameter was lower in the seedling treated with microbial biostimulants and decreased as salt stress increased.

The unstressed seedlings had a higher stomatal conductance when inoculated with the microbial biostimulants treatment but recorded a reduction of this parameter under salt stress to values similar to those of control seedlings (Table 4).

The relative water content (RWC) was significantly lowered at each salt stress level in control seedlings ranging from 92.6 to $69.7 \%$ whereas the seedlings inoculated with microbial biostimulants and irrigated with $25 \mathrm{mM} \mathrm{NaCl}$ in the irrigation water reduced their RWC to values similar to those recorded in the control with no further significant decrease at the highest salinity level (Table 4).

Leaf color was affected only by irrigation water salinity. The highest salt stress level increased leaf color lightness $\left(\mathrm{L}^{*}\right)$ and reduced its vividness as showed by the lower value of Chroma (Table 4). 
Table 4. Effects of microbial biostimulant treatment (C, not treated; $\mathrm{B}$, Bactorr ${ }^{\mathrm{S} 13}$; $\mathrm{M}$, Flortis Micorrize) and salt stress $(0,25$, and $50 \mathrm{mM} \mathrm{NaCl}$ in the irrigation water) on the leaf characteristics of tomato seedlings.

\begin{tabular}{|c|c|c|c|c|c|c|c|c|c|}
\hline Source of Variance & $\begin{array}{c}\text { Number } \\
\text { of } \\
\text { Leaves }\end{array}$ & $\begin{array}{l}\text { Leaf Area } \\
\quad\left(\mathrm{cm}^{2}\right. \\
\left.\text { Seedling }^{-1}\right)\end{array}$ & $\begin{array}{c}\text { Leaf Area } \\
\left(\mathrm{cm}^{2}\right. \\
\left.\text { Leaf }^{-1}\right)\end{array}$ & $\begin{array}{l}\text { SLA y } \\
\left(\mathrm{cm}^{2} \mathrm{~g}\right. \\
\left.\mathrm{DW}^{-1}\right)\end{array}$ & 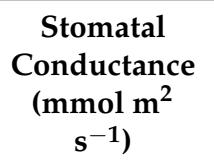 & $\begin{array}{c}\text { RWC } \\
(\%)\end{array}$ & $\mathbf{L}^{*}$ & Chroma & Hue $^{\circ}$ \\
\hline \multicolumn{10}{|l|}{ Treatment } \\
\hline C & $\mathrm{z} 4.9 \mathrm{~b}$ & 44.5 & $9.1 b$ & $540.2 \mathrm{a}$ & 392.2 & 84.3 & 45.1 & 30.2 & 127.6 \\
\hline B & $5.2 \mathrm{a}$ & 49.2 & $9.5 \mathrm{ab}$ & $503.7 \mathrm{~b}$ & 454.4 & 89.5 & 45.0 & 30.1 & 127.1 \\
\hline M & $5.1 \mathrm{a}$ & 50.4 & $9.9 a$ & $493.5 b$ & 358.1 & 90.3 & 45.1 & 30.4 & 127.4 \\
\hline \multicolumn{10}{|l|}{$\mathrm{NaCl}(\mathrm{mM})$} \\
\hline 0 & $5.2 \mathrm{a}$ & 52.7 & $10.2 \mathrm{a}$ & $547.1 \mathrm{a}$ & 545.4 & 92.1 & $45.4 \mathrm{a}$ & $30.8 \mathrm{a}$ & 127.2 \\
\hline 25 & $5.1 \mathrm{a}$ & 49.9 & $9.8 \mathrm{a}$ & $523.8 b$ & 358.0 & 89.9 & $45.3 a$ & $30.6 a$ & 127.2 \\
\hline 50 & $4.9 \mathrm{~b}$ & 41.4 & $8.5 b$ & $466.4 \mathrm{c}$ & 301.2 & 82.1 & $44.5 b$ & $29.3 b$ & 127.7 \\
\hline \multicolumn{10}{|l|}{ Treatment $\times \mathrm{NaCl}$} \\
\hline \multirow[t]{3}{*}{$\mathrm{C}$} & 4.9 & $48.0 \mathrm{~b}$ & 9.7 & 554.8 & $389.7 \mathrm{~b}$ & $92.6 \mathrm{a}$ & 45.9 & 31.4 & 127.0 \\
\hline & 4.9 & $46.1 \mathrm{~b}$ & 9.5 & 568.7 & $385.0 \mathrm{~b}$ & $90.6 \mathrm{ab}$ & 45.3 & 30.1 & 127.6 \\
\hline & 4.9 & $39.4 \mathrm{c}$ & 8.1 & 497.2 & $401.8 \mathrm{~b}$ & $69.7 \mathrm{c}$ & 44.1 & 29.0 & 128.1 \\
\hline \multirow[t]{3}{*}{ B } & 5.4 & $55.9 a$ & 10.5 & 548.9 & $759.8 \mathrm{a}$ & $90.8 \mathrm{ab}$ & 45.4 & 30.5 & 127.1 \\
\hline & 5.2 & $49.4 b$ & 9.5 & 504.2 & $354.4 b$ & $88.9 b$ & 45.0 & 30.2 & 127.2 \\
\hline & 5.0 & $42.4 \mathrm{c}$ & 8.6 & 458.1 & $249.0 \mathrm{~b}$ & $88.8 b$ & 44.7 & 29.6 & 127.1 \\
\hline \multirow{4}{*}{$\begin{array}{lc}\text { M } & 0 \\
& 25 \\
& 50 \\
\text { Sionificance } & \mathrm{x}\end{array}$} & 5.2 & $54.2 \mathrm{a}$ & 10.4 & 537.7 & $486.8 \mathrm{ab}$ & $93.0 \mathrm{a}$ & 45.1 & 30.4 & 127.5 \\
\hline & 5.2 & $54.4 \mathrm{a}$ & 10.5 & 498.6 & $334.7 \mathrm{~b}$ & $90.1 \mathrm{ab}$ & 45.7 & 31.5 & 126.9 \\
\hline & 4.8 & $42.6 c$ & 8.9 & 444.1 & $252.8 b$ & $87.8 \mathrm{~b}$ & 44.5 & 29.3 & 127.8 \\
\hline & \multicolumn{9}{|c|}{ Significance $^{x}$} \\
\hline Treatment & $* *$ & $* * *$ & $* *$ & $* * *$ & ns & $* *$ & ns & $\mathrm{ns}$ & ns \\
\hline $\mathrm{NaCl}$ & $* *$ & $* * *$ & $* * *$ & $* * *$ & $* * *$ & $* * *$ & $* * *$ & $* *$ & ns \\
\hline Treatment $\times \mathrm{NaCl}$ & ns & $* *$ & ns & ns & $* *$ & $* * *$ & ns & ns & ns \\
\hline
\end{tabular}

${ }^{\mathrm{z}}$ Each value is the mean of four replicated samples of 30 seedlings each. For each factor, values in a column followed by the same letter are not significantly different, according to the LSD test. ${ }^{x}$ Significance: $\mathrm{ns}=$ not significant; ${ }^{*}$ significant at $p<0.05 ;{ }^{* *}$ significant at $p<0.01$; ${ }^{* * *}$ significant at $p<0.001 ;^{\text {y }}$ Specific leaf area.

\subsection{Principal Components Analysis}

Two principal components (PCs) with eigenvalues higher than 1.00 resulted from the principal components analysis performed on the morphophysiological parameters of lettuce and tomato seedlings (Table 5). They represent $68.66 \%$ and $20.93 \%$ of the total variance, respectively, and their combination could represent the initial twenty-three variables, explaining $89.60 \%$ of the total variance.

PC1 was mainly related to height, total, root, and stem fresh weight (FW), shoot/root (S/R) FW, total, root, stem, and leaf dry weight (DW), shoot/root (S/R) DW, dry matter percentage, water use efficiency (WUE), specific leaf area (SLA), L*, Chroma, and Hue angle; PC2 was related to stem diameter, leaf fresh weight (FW), leaf number, plant and leaf area, and stomatal conductance (Table 5). The projection of the original variables on the plane of the two PCs displayed in the plot of loadings (Figure 6a) illustrates such relationships.

The differentiation of the $\mathrm{NaCl}$ levels supplied with the irrigation water to lettuce and tomato seedlings inoculated with Bactorr ${ }^{\mathrm{S} 13}$ or Flortis Micorizze or not inoculated are shown in the plot of scores (Figure 6b), where two main clusters (lettuce and tomato seedlings) could be visibly distinguished. The scores of lettuce seedlings were located in the negative part of the PC1 axis, whereas tomato seedlings were located in the positive part of the PC1 axis; the lettuce and tomato seedlings inoculated with the microbial biostimulants watered with 0 or $25 \mathrm{mM} \mathrm{NaCl}$ in the irrigation water and the unstressed control seedlings were located in the positive part of the PC2 axis, whereas all the other treatments were located in the negative part of the PC2 axis. Some sub-clusters for each main cluster could be distinguished. Tomato $B$ with $0 \mathrm{mM} \mathrm{NaCl}$ and Tomato $\mathrm{M}$ with 0 and $25 \mathrm{mM} \mathrm{NaCl}$ can be grouped together; a second tomato sub-cluster is composed of control seedlings with 
0 and $25 \mathrm{mM} \mathrm{NaCl}$ and $\mathrm{B}$ seedlings with $25 \mathrm{mM} \mathrm{NaCl}$, and a third tomato sub-cluster is composed of all the seedlings grown under the highest salinity level. The inoculated unstressed lettuce seedlings can be grouped in the first lettuce sub-cluster, the second subcluster is composed of unstressed control seedlings and inoculated salt-stressed seedlings ( 25 and $50 \mathrm{mM} \mathrm{NaCl}$ ), and the third lettuce sub-cluster is composed of salt-stressed control seedlings.

Combining the data from the plot of loadings and scores, it can be concluded that the concentration of $\mathrm{NaCl}$ in the irrigation water influenced the lettuce and tomato seedlings in different ways according to the microbial biostimulant treatments (Figure 6a,b).

Table 5. Correlation of variables of lettuce and tomato seedlings to the factors of the principal components analysis (PCA) based on factor loadings.

\begin{tabular}{ccc}
\hline Variable & PC1 & PC2 \\
\hline Height & 0.963 & 0.172 \\
Stem diameter & -0.594 & $\mathbf{0 . 7 7 8}$ \\
Total fresh weight & $\mathbf{0 . 9 5 4}$ & 0.259 \\
Root fresh weight & $\mathbf{0 . 9 5 4}$ & 0.225 \\
Stem fresh weight & $\mathbf{0 . 9 7 2}$ & 0.023 \\
Leaf fresh weight & 0.074 & $\mathbf{0 . 9 5 1}$ \\
Shoot/Root FW & $\mathbf{0 . 7 9 3}$ & 0.327 \\
Total dry weight & $\mathbf{0 . 9 9 4}$ & 0.035 \\
Root dry weight & $\mathbf{0 . 9 8 4}$ & 0.087 \\
Stem dry weight & $\mathbf{0 . 9 8 8}$ & -0.046 \\
Leaf dry weight & $\mathbf{0 . 9 7 6}$ & 0.147 \\
Shoot/Root DW & $\mathbf{0 . 9 3 9}$ & -0.102 \\
Dry matter \% & $\mathbf{0 . 8 9 1}$ & -0.345 \\
RWC & -0.531 & 0.546 \\
WUE & $\mathbf{0 . 8 9 3}$ & 0.251 \\
Leaf number & -0.414 & $\mathbf{0 . 7 6 5}$ \\
Plant area & 0.429 & $\mathbf{0 . 8 7 5}$ \\
Leaf area & 0.607 & $\mathbf{0 . 7 3 3}$ \\
SLA & $\mathbf{0 . 9 4 8}$ & 0.287 \\
L* & 0.217 & $\mathbf{0 . 6 4 1}$ \\
Chroma & $\mathbf{0 . 9 6 3}$ & 0.223 \\
Hue & $\mathbf{0 . 9 6 5}$ & 0.240 \\
Stomatal conductance & $\mathbf{0 . 9 7 0}$ & -0.197 \\
\hline
\end{tabular}

Values in bold within the same factor indicate the variable with the largest correlation. 

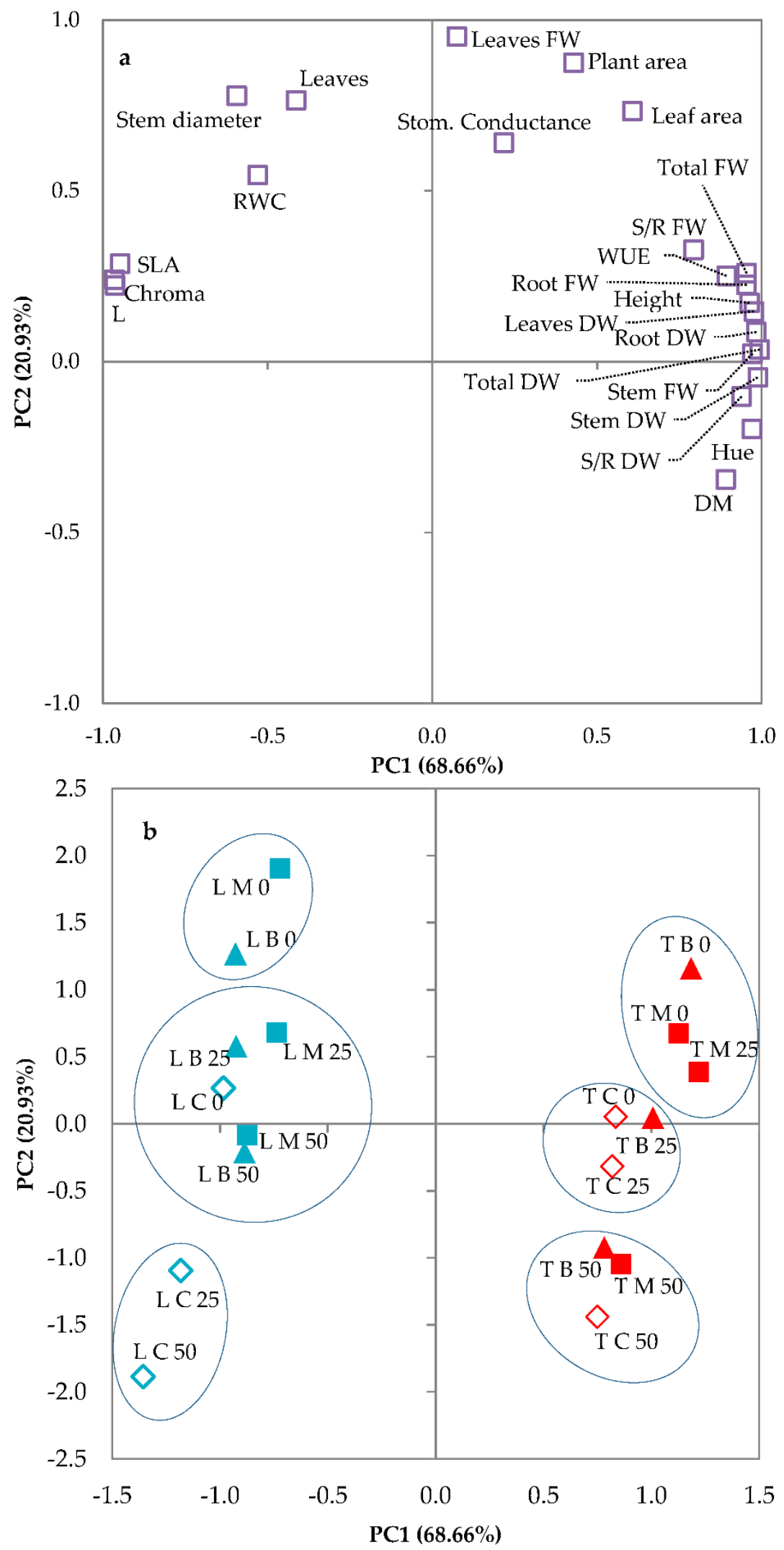

Figure 6. Plots of (a) loadings (morphophysiological characteristics of lettuce and tomato seedlings) and (b) scores (trials) formed by the two principal components from the Principal Component Analysis (PCA). L C: untreated lettuce seedlings; L B: lettuce seedlings inoculated with Bactorr ${ }^{\mathrm{S} 13}$; L M: lettuce seedlings inoculated with Micorrize; T C: untreated tomato seedlings; T B: tomato seedlings inoculated with Bactorr ${ }^{S 13}$; T M: tomato seedlings inoculated with Flortis Micorrize; 0, 25, and 50: concentration of $\mathrm{NaCl}(\mathrm{mM})$ in the irrigation water. 


\section{Discussion}

The main aim of the vegetable nursery is to produce high-quality and vigorous transplants in a short time. Seedling development and size at transplanting have been related to establishment success, vigor, and yield of vegetable crops, so transplant quality has a big relevance also for vegetable growers [48-52]. To reduce the production time and increase seedling vigor, transplant production requires intensive and frequent resource use including daily applications of water and high concentrations of fertilizers [53]. Thus, the availability of good quality water is of paramount importance for nursery growers, but, always more often, brackish water is the only available water source in the areas where vegetable transplants are more required. In a previous study [21], we found that the salt tolerance of tomato and sweet pepper transplants could be increased with the application of gibberellic acid. In this work, we investigated the chances to enhance the salt tolerance of lettuce and tomato seedlings and produce vegetable transplants with good quality characteristics by inoculating the growth substrate with microbial biostimulants.

Uninoculated lettuce and tomato seedlings irrigated with saline water suffered a decrease in biomass accumulation and growth limitations even with different salinity tolerance thresholds. The negative effects of salinity variously altered the morphological and physiological characteristics of lettuce and tomato transplants such as seedling height, stem diameter, shoot/root ratio, water use efficiency, leaf number, leaf area, leaf water status, and stomatal conductance. Many vegetable crops suffer similar alteration when grown under salt stress in open fields or nurseries [20,54-56].

Seedling height recorded a significant reduction up to 25 and $30 \%$ in tomato and lettuce untreated seedlings irrigated with the highest water salinity level $(50 \mathrm{mM} \mathrm{NaCl})$. Lettuce seedlings also suffered a significant reduction $(-18 \%)$ at the intermediate salt stress level $(25 \mathrm{mM} \mathrm{NaCl})$. The use of brackish water for seedling irrigation affected total fresh and dry biomass of the untreated seedlings of both lettuce and tomato, but these species showed different tolerance thresholds, confirming that vegetables' tolerance to salinity can vary greatly and salt stress effects can increase with different extents according to the increase of salinity level $[57,58]$. Biomass reductions were higher in lettuce $(-38.7 \%$ and $-34.8 \%$ with $50 \mathrm{mM} \mathrm{NaCl}$ for total fresh and dry weight, respectively) than tomato $(-24.8 \%$ and $-13.8 \%$ with $50 \mathrm{mM} \mathrm{NaCl}$ for total fresh and dry weight, respectively). Tomato seedlings were significantly affected only at the highest salinity level whereas lettuce seedlings progressively decreased their biomass by increasing the salt stress level $(-17.8 \%$ and $-23.3 \%$ with $25 \mathrm{mM} \mathrm{NaCl}$ for total fresh and dry weight, respectively). Salinity slows tomato shoot growth more than root growth, especially at the seedling stage when the younger the salinized seedling the less the shoot growth [59]. Our results confirmed that tomato seedlings treated with high $\mathrm{NaCl}$ concentrations $\left(50 \mathrm{mM} ; 5.57 \mathrm{dS} \mathrm{m}^{-1}\right)$ suffer significant reductions of different growth traits [60]. The threshold of tolerance after which tomato root weight decreases as salinity increases is between $4 \mathrm{dS} \mathrm{m}^{-1}$ and $6 \mathrm{dS} \mathrm{m}^{-1}$ whereas shoot growth and yield are reduced at lower salinity levels [59]. The threshold salinity of lettuce plants is lower than tomato and falls between $1.1 \mathrm{dS} \mathrm{m}^{-1}$ and $2.0 \mathrm{dS} \mathrm{m}^{-1}$ [61,62]. This can explain the higher effect of salinity found at moderate salt stress in lettuce seedlings. Irrigation water salinity above $2.8 \mathrm{dS} . \mathrm{m}^{-1}$ can significantly reduce the development of lettuce cultivars [63] as also confirmed by our experiment in which lettuce seedlings suffered significant reductions of different growth traits at the intermediate salt stress $(25 \mathrm{mM} \mathrm{NaCl})$ corresponding to an EC value of $3.14 \mathrm{dS} \mathrm{m}^{-1}$.

Soil or irrigation water salinity affects plant growth and its metabolism in many ways. Salinity increases the electrical conductivity (EC) of the soil solution, thus, increasing its osmotic potential that limits water availability to the plants and determines reduced water uptake and partial dehydration of the cell cytoplasm as confirmed by the decrease of the relative water content recorded in lettuce and tomato seedlings. It also modifies plant nutrient uptake due to a negative effect on nutrient availability $[55,57]$ and affects nutrient translocation from the roots to the shoot. These negative effects may slow down or even stop plant growth, change biomass partitioning and plant morphology [64-66] 
as shown by the variations in biomass accumulation, fresh weight shoot/root ratios, and reduction of leaf number and leaf expansion observed in lettuce and tomato seedlings [60]. Growth limitations determined by salt stress can negatively affect the size and quality of transplants that are related to establishment success, growth rate, and yield of the crop $[10,11]$. As the quality of transplants is linked to their commercial success, salinity issues should be carefully addressed by vegetable nurseries.

The inoculation of the substrate with the microbial biostimulants exerted a growthpromoting effect on the unstressed lettuce and tomato seedlings but this effect differed for Bactorr $^{\mathrm{S} 13}$ (B) and Flortis Micorrize (M) as a function of the species and the morphophysiological parameter. The microbial consortia similarly affected some growth parameters whereas others were improved to a greater extent by B or by $\mathrm{M}$, but both biostimulants had a higher growth-promoting effect in lettuce than tomato. The inoculation of the substrate with the bacterial inoculant (B; Bactorr ${ }^{\mathrm{S} 13}$, a mix of Bacillus spp.) increased the total fresh weight of lettuce and tomato seedlings by $27.0 \%$ and $13.9 \%$, respectively, compared to the respective untreated seedlings. The microbial biostimulant $(\mathrm{M})$ containing a mix of bacteria and fungi (Agrobacterium radiobacter, Bacillus subtilis, Streptomyces spp., Glomus spp. and Trichoderma spp.) increased the fresh weight by $53.3 \%$ and $8.6 \%$ in lettuce and tomato seedling, respectively. The differences between the two biostimulants on each vegetable species were smaller on a dry weight basis but their effect was still greater on lettuce than tomato $(+28.8 \%$ and $+38.9 \%$ in lettuce and $+16.9 \%$ and $+18.1 \%$ in tomato for $\mathrm{B}$ and $\mathrm{M}$, respectively, compared to the total dry weight of the respective untreated seedlings). The increased biomass accumulation determined by the microbial biostimulants was differently partitioned in lettuce and tomato seedlings as resulted from the decrease of the shoot/root ratio in lettuce and its increase in tomato thanks to the increase of stem and leaf biomass in both species and root biomass in lettuce only. The increase of leaf weight in the inoculated seedlings corresponded to a higher number of leaves, mainly in the seedlings inoculated with B. The total leaf area was similarly increased by B and $\mathrm{M}$ in tomato $(+14.8 \%$ on average) and twice by $\mathrm{M}(+49.3 \%)$ than $\mathrm{B}(+21.4 \%)$ in lettuce.

It is well known that species of Bacillus, Paenibacillus, and Streptomyces, like those present in Bactorr ${ }^{\mathrm{S} 13}$ and Flortis Micorrize, can exert a plant growth-promoting effect [9,67-69]. Inoculation of lettuce plants by adding a bacterial suspension of B. amyloliquefaciens, B. subtilis or B. licheniformis or other Bacillus spp. to the substrate resulted in improved shoot and root weight [70-73], as also found in our work using microbial inoculants containing Bacillus spp. (both B and $\mathrm{M}$ inoculants). A similar effect of various Bacillus spp. (B. circulans, B. velezensis, B. subtilis, $B$. pumilus, etc.) and Streptomyces strains was found on inoculated tomato plants [74-78]. The main growth-promoting mechanisms of these bacteria involve the production of growth-promoting phytohormones (cytokinin, gibberellins, indole-acetic acid) or the rebalancing of endogenous hormone content, inhibition of plant ethylene synthesis, solubilization and mobilization of phosphate, promotion of nitrogen uptake, production of siderophore, antibiosis, and induction of plant systemic resistance to pathogens $[69,70,77,79]$. Bacillus strains application showed to be successful in improving plant growth under greenhouse or field conditions for several vegetable crops (broccoli, cucumber, pepper, tomato, and lettuce) $[8,9,43]$.

Enhanced growth can be also obtained by inoculating the soil with mycorrhizal fungi $[80,81]$ and Glomus is one of the commonly occurring genera of AMF in the soil and was present in the mycorrhizal inoculum (Flortis Micorrize) used in this work. The plant growth improvements due to AMF inoculation are ascribed to the enhanced uptake from the soil of nutrients with a limited diffusion $(\mathrm{P}, \mathrm{Zn}, \mathrm{Cu}$, etc.), the ability to withstand water stress, the production of phytohormones, their role in the biological control of soilborne pathogens, and the synergistic interaction with other plant growth-promoting rhizo-microorganisms such as Trichoderma spp. [34]. The inoculation of the substrate with Bacillus spp. or with a consortium of AMF + PGPR has been reported to promote plant growth and to be beneficial for raising healthy and vigorous lettuce, tomato, and capsicum transplants [9,82]. The interaction between bacteria or AMF and plants can have various effects due to the crop species or even to the soil conditions [83]. The mix of microbial 
strains could determine different interactions and synergistic or antagonistic effects that can be also driven by the differences in root exudates, hence, the efficacy of a microbial consortium could differ when applied to different crops [41]. This can explain the different levels of growth-promoting effect determined by the microbial biostimulants on lettuce and tomato $[34,84,85]$.

The use of microbial biostimulants was also effective in modifying the tolerance of seedlings to salt stress even if with different responses for lettuce and tomato. The treatment with $\mathrm{B}$ and $\mathrm{M}$ delayed the beginning of salt stress symptoms and limited growth reduction of tomato seedlings grown at the intermediate salinity level $(25 \mathrm{mM} \mathrm{NaCl})$. Under this condition, the accumulation of fresh biomass in the inoculated tomato seedlings was similar to the unstressed untreated seedlings and dry biomass and leaf area were higher, especially in salt-stressed tomato seedlings inoculated with $\mathrm{M}$. The effects of the microbial biostimulants were more evident on lettuce seedlings that had values of the growth parameters comparable to unstressed untreated seedlings when inoculated with $\mathrm{B}$ also if grown at the highest salinity level, or even higher than unstressed untreated seedlings when inoculated with M. Moreover, the lettuce seedlings inoculated with the microbial biostimulants resulted more efficient than control in using the irrigation water under salt stress (WUE increased by $42.5 \%$ on average at $25 \mathrm{mM} \mathrm{NaCl}$ and by $67.8 \%$ on average at $50 \mathrm{mM} \mathrm{NaCl}$ compared to the control seedlings at the same salinity levels). An improvement of water use efficiency was also recorded in the salt-stressed inoculated tomato seedlings, but the seedlings inoculated with $\mathrm{M}(+28.5 \%$ and $+13.2 \%$ with 25 and $50 \mathrm{mM} \mathrm{NaCl}$, respectively, compared to the control seedlings at the same salinity levels) had an almost twice as big increase of WUE than those with B in both salinity treatments $(+14.5 \%$ and $+7.4 \%$ with 25 and $50 \mathrm{mM} \mathrm{NaCl}$ respectively, compared to the control seedlings at the same salinity levels). Different plant growth-promoting microorganisms have been tested successfully to enhance salinity tolerance of lettuce and tomato plants under various growth conditions [56,86-90], confirming the beneficial effect determined by the microbial biostimulants used in our trial.

It is well known that the use of microbes with plant growth-promoting activity can also mitigate some abiotic stresses such as salinity [91]. The growth-stimuli effect of rhizobacteria, endo- and ectomycorrhizal fungi, and many other microorganisms led to improvements in the tolerance to salt stress of various crop plants, such as tomato, pepper, bean, and lettuce [92]. Vigorous plants can better face salt stress by increasing salt tolerance threshold or by delaying the onset of its effects [93]. The application of microbial biostimulants can be successful in increasing seedling growth and vigor, as shown in our work, and can affect metabolism so helping plants to better deal with salt stress [56].

The increased tolerance to salinity determined by PGPR could be ascribed to various mechanisms including changes in phytohormone homeostasis, antioxidant defense, osmolyte production, ACC (1-aminocyclopropane-1-carboxylate) deaminase activity, and biofilm formation [78,94-98].

Various studies reported that mycorrhizal fungal symbioses can improve plant growth and yield and enhance tolerance under salt stress in many host plants [99,100]. Colonization with AMF can improve dry matter and leaf area in tomato salt-stressed plants as found in our work [101]. The growth promotion recorded in mycorrhizal plants grown under salt stress has been related to a variety of mechanisms. Mycorrhization can increase the chlorophyll content of inoculated lettuce plants under salt stress to a level even higher than non-stressed plants, allowing them to fully counterbalance stress [102]. AMF inoculation can increase the uptake of nutrients in the host plant and the $\mathrm{K}^{+} / \mathrm{Na}^{+}$ratios in plant tissues and, thus, improves the photosynthetic rate as well as water osmotic homeostasis even in saline environments $[102,103]$ thanks to a more efficient osmotic adjustment by the accumulation of solutes such as soluble sugars, betaine, glycine, or proline [104]. Arbuscular mycorrhizal plants show an enhanced activity of antioxidant enzymes that better deal with the reactive oxygen species caused by salt stress conditions. Arbuscular mycorrhizal symbiosis can also act at the molecular level by modulating the expression of 
plant genes encoding aquaporins [105] and late embryogenesis abundant proteins [106] or involved in the biosynthesis of proline [105]. The different regulation of these genes in salt-stressed mycorrhizal plants allows them to preserve a higher water status in their tissues [104], as found in our work in lettuce and tomato seedling inoculated with the mycorrhizal biostimulant.

Among plant growth-promoting fungi, Trichoderma spp. have been shown to promote plant growth and increase the tolerance to environmental stresses of many crops. This microorganism was part of the Flortis Micorrize biostimulant. Trichoderma strains can improve plant tolerance to salinity by improving nutritional uptake, root development, osmolyte production (L-proline and ascorbic acid), $\mathrm{Na}^{+}$elimination, and increasing protection against oxidative damage and gene expression [107-110]. The inoculation of Trichoderma strains to plants grown in saline environments alleviated the negative effect of $\mathrm{NaCl}$ in different species $[109,111,112]$. Trichoderma inoculated plants produced phytohormones (cytokinins, gibberellins, salicylic acid, and jasmonic acid) that can induce enhanced growth and development of the plants and counteract the generation of reactive oxygen species even under $\mathrm{NaCl}$ stress $[112,113]$.

The results of our work showed that the response of lettuce and tomato seedlings to the inoculation with microbial biostimulants and the alleviation of salt stress determined by the inoculants varied according to the species and the microbial biostimulant considered. These differences were clearly underlined by the principal component analysis. The interaction between plants and beneficial microbes is very complex and may vary from crop to crop and growth stages [92]. Root exudates activate the microbial chemotaxis towards plant roots and could enhance or reduce root colonization and plant-driven selection of microorganisms $[114,115]$. Thus, the variation in root exudate composition found in different plant genotypes can modify the host specificity in microbes-plant interactions and could affect the competition among the microorganisms of the microbial consortium, resulting in different levels of plant growth promotion [116].

Every microorganism inoculated through the microbial biostimulants could have determined the growth-promoting effect on lettuce and tomato seedlings. The interaction between AMF, PGPR, and other microbes (microbial consortium) may determine a synergistic effect that was confirmed by improved plant growth, nutrition, and yield as well as mitigated salinity stress in lettuce, tomato, and other crops [13,56,82,85,117-119]. As showed by the values of the morpho-physiological parameters and PCA, the consortium of microorganisms with the highest biodiversity was more effective in alleviating salt stress.

\section{Conclusions}

Nursery transplant production of lettuce and tomato seedlings was affected by the salinity of irrigation water that negatively influenced biomass accumulation, leaf number, leaf area, and seedling quality. Lettuce seedlings were more sensitive to salinity and suffered significant negative effects even with moderate salt stress $(25 \mathrm{mM} \mathrm{NaCl})$, whereas tomato seedlings suffered a significant growth reduction only with the highest salt stress $(50 \mathrm{mM} \mathrm{NaCl})$.

The inoculation of the substrate with microbial biostimulants exerted a growthpromoting effect on the unstressed lettuce and tomato seedlings and was also effective in modifying the tolerance of seedlings to salt stress but with some differences for Bactorr ${ }^{\mathrm{S} 13}$ (B) and Flortis Micorrize (M) and different responses for lettuce and tomato. The treatment with $\mathrm{B}$ and $\mathrm{M}$ delayed the beginning of salt stress symptoms and limited growth reduction of tomato seedlings at the intermediate salinity level $(25 \mathrm{mM} \mathrm{NaCl})$ especially in salt-stressed tomato seedlings inoculated with $\mathrm{M}$, whereas lettuce seedlings had values of the growth parameters comparable to unstressed untreated seedlings when inoculated with $\mathrm{B}$ or higher when inoculated with $\mathrm{M}$, even if grown at the highest salinity level.

Thus, the use of microbial biostimulants, especially in the case of the consortium containing a mix of bacteria and fungi (Agrobacterium radiobacter, Bacillus subtilis, Streptomyces spp., Glomus spp. and Thricoderma spp.) can be a sustainable means to alleviate salt 
stress symptoms and increase salinity tolerance of lettuce and tomato seedlings, allowing the production of good quality transplants even when the scarcity of good quality water makes the use of brackish water a necessity.

Author Contributions: Conceptualization, A.M. (Alessandro Miceli), A.M. (Alessandra Moncada) and F.V.; data curation, A.M. (Alessandro Miceli) and F.V.; formal analysis, A.M. (Alessandro Miceli), A.M. (Alessandra Moncada) and F.V.; investigation, A.M. (Alessandro Miceli), A.M. (Alessandra Moncada) and F.V.; methodology, A.M. (Alessandro Miceli), A.M. (Alessandra Moncada) and F.V.; supervision, A.M. (Alessandro Miceli) and F.V.; validation, A.M. (Alessandro Miceli) and A.M. (Alessandra Moncada); writing —original draft, A.M. (Alessandro Miceli), A.M. (Alessandra Moncada) and F.V.; writing-review and editing, A.M. (Alessandro Miceli) and A.M. (Alessandra Moncada). All authors have read and agreed to the published version of the manuscript.

Funding: This research received no external funding.

Institutional Review Board Statement: Not applicable.

Informed Consent Statement: Not applicable.

Conflicts of Interest: The authors declare no conflict of interest.

\section{References}

1. Bartels, D.; Sunkar, R. Drought and salt tolerance in plants. CRC Crit. Rev. Plant Sci. 2005, 24, 23-58. [CrossRef]

2. Läuchli, A.; Grattan, S.R. Plant Growth and Development under Salinity Stress. In Advances in Molecular Breeding Toward Drought and Salt Tolerant Crops; Springer: Dordrecht, The Netherlands, 2007; pp. 1-32. ISBN 978-1-40205-577-5.

3. Läuchli, A.; Grattan, S.R. Plant Responses to Saline and Sodic Conditions. In Agricultural Salinity Assessment and Management; American Society of Civil Engineers: Reston, VA, USA, 2011; pp. 169-205. ISBN 978-0-78447-648-2.

4. Munns, R.; Tester, M. Mechanisms of Salinity Tolerance. Annu. Rev. Plant Biol. 2008, 59, 651-681. [CrossRef] [PubMed]

5. Snapp, S.S.; Shennan, C.; Bruggen, A.H.C. Effects of salinity on severity of infection by Phytophthora parasitica Dast., ion concentrations and growth of tomato, Lycopersicon esculentum Mill. New Phytol. 1991, 119, 275-284. [CrossRef]

6. Foolad, M.R. Recent Advances in Genetics of Salt Tolerance in Tomato. Plant Cell. Tissue Organ Cult. 2004, 76, 101-119. [CrossRef]

7. Kloepper, J.W.; Reddy, M.S.; Rodriguez-Kabana, R.; Kenney, D.S.; Kokalis-Burelle, N.; Martinez-Ochoa, N.; Vavrina, C.S. Application for rhizobacteria in transplant production and yield enhancement. Acta Hortic. 2004, 631, 217-229. [CrossRef]

8. Moncada, A.; Vetrano, F.; Esposito, A.; Miceli, A. Fertigation Management and Growth-Promoting Treatments Affect Tomato Transplant Production and Plant Growth after Transplant. Agronomy 2020, 10, 1504. [CrossRef]

9. Vetrano, F.; Miceli, C.; Angileri, V.; Frangipane, B.; Moncada, A.; Miceli, A. Effect of Bacterial Inoculum and Fertigation Management on Nursery and Field Production of Lettuce Plants. Agronomy 2020, 10, 1477. [CrossRef]

10. Gama, P.B.S.; Inanaga, S.; Tanaka, K.; Nakazawa, R. Physiological response of common bean (Phaseolus vulgaris L.) seedlings to salinity stress. Afr. J. Biotechnol. 2007, 6, 79-88.

11. Bayuelo-Jiménez, J.S.; Debouck, D.G.; Lynch, J.P. Growth, gas exchange, water relations, and ion composition of Phaseolus species grown under saline conditions. Field Crop. Res. 2003, 80, 207-222. [CrossRef]

12. Mariani, L.; Ferrante, A. Agronomic Management for Enhancing Plant Tolerance to Abiotic Stresses-Drought, Salinity, Hypoxia, and Lodging. Horticulturae 2017, 3, 52. [CrossRef]

13. Kumawat, K.C.; Sharma, P.; Nagpal, S.; Gupta, R.K.; Sirari, A.; Nair, R.M.; Bindumadhava, H.; Singh, S. Dual Microbial Inoculation, a Game Changer?-Bacterial Biostimulants With Multifunctional Growth Promoting Traits to Mitigate Salinity Stress in Spring Mungbean. Front. Microbiol. 2021, 11, 600576. [CrossRef] [PubMed]

14. Vurukonda, S.S.K.P.; Vardharajula, S.; Shrivastava, M.; SkZ, A. Enhancement of drought stress tolerance in crops by plant growth promoting rhizobacteria. Microbiol. Res. 2016, 184, 13-24. [CrossRef] [PubMed]

15. Shahbaz, M.; Ashraf, M. Improving Salinity Tolerance in Cereals. CRC Crit. Rev. Plant Sci. 2013, 32, 237-249. [CrossRef]

16. Dajic, Z. Salt stress. In Physiology and Molecular Biology of Stress Tolerance in Plants; Rao, K., Raghavendra, A., Eddy, K., Eds.; Kluwer Academic Publishers: Dordrecht, The Netherlands, 2006; pp. 41-99.

17. Wang, Y.; Mopper, S.; Hasenstein, K.H. Effects of salinity on endogenous ABA, IAA, JA, and SA in Iris hexagona. J. Chem. Ecol. 2001, 27, 327-342. [CrossRef] [PubMed]

18. Egamberdieva, D. Alleviation of salt stress by plant growth regulators and IAA producing bacteria in wheat. Acta Physiol. Plant. 2009, 31, 861-864. [CrossRef]

19. Abiri, R.; Shaharuddin, N.A.; Maziah, M.; Yusof, Z.N.B.; Atabaki, N.; Sahebi, M.; Valdiani, A.; Kalhori, N.; Azizi, P.; Hanafi, M.M. Role of ethylene and the APETALA 2/ethylene response factor superfamily in rice under various abiotic and biotic stress conditions. Environ. Exp. Bot. 2017, 134, 33-44. [CrossRef]

20. Vetrano, F.; Moncada, A.; Miceli, A. Use of Gibberellic Acid to Increase the Salt Tolerance of Leaf Lettuce and Rocket Grown in a Floating System. Agronomy 2020, 10, 505. [CrossRef] 
21. Miceli, A.; Vetrano, F.; Moncada, A. Effects of Foliar Application of Gibberellic Acid on the Salt Tolerance of Tomato and Sweet Pepper Transplants. Horticulturae 2020, 6, 93. [CrossRef]

22. Dodd, I.C.; Zinovkina, N.Y.; Safronova, V.I.; Belimov, A.A. Rhizobacterial mediation of plant hormone status. Ann. Appl. Biol. 2010, 157, 361-379. [CrossRef]

23. Gupta, S.; Pandey, S. ACC deaminase producing bacteria with multifarious plant growth promoting traits alleviates salinity stress in French Bean (Phaseolus vulgaris) plants. Front. Microbiol. 2019, 10. [CrossRef]

24. Gouda, S.; Kerry, R.G.; Das, G.; Paramithiotis, S.; Shin, H.-S.; Patra, J.K. Revitalization of plant growth promoting rhizobacteria for sustainable development in agriculture. Microbiol. Res. 2018, 206, 131-140. [CrossRef]

25. Grobelak, A.; Kokot, P.; Hutchison, D.; Grosser, A.; Kacprzak, M. Plant growth-promoting rhizobacteria as an alternative to mineral fertilizers in assisted bioremediation-Sustainable land and waste management. J. Environ. Manage. 2018, 227, 1-9. [CrossRef]

26. Nagargade, M.; Tyagi, V.; Singh, M. Plant Growth-Promoting Rhizobacteria: A Biological Approach toward the Production of Sustainable Agriculture Extension. In Role of Rhizospheric Microbes in Soil; Meena, V., Ed.; Springer: Singapore, 2018; Volume 1, pp. 205-223. [CrossRef]

27. Berg, G. Plant-microbe interactions promoting plant growth and health: Perspectives for controlled use of microorganisms in agriculture. Appl. Microbiol. Biotechnol. 2009, 84, 11-18. [CrossRef] [PubMed]

28. Abdel-Fattah, G.M.; Mohamedin, A.H. Interactions between a Vesicular-Arbuscular Mycorrhizal Fungus (Glomus Intraradices) and Streptomyces Coelicolor and their Effects on Sorghum Plants Grown in Soil Amended with Chitin of Brawn Scales; Springer: Berlin/Heidelberg, Germany, 2000; Volume 32.

29. Du Jardin, P. Plant biostimulants: Definition, concept, main categories and regulation. Sci. Hortic. 2015, 196, 3-14. [CrossRef]

30. Kumar, A.; Dames, J.F.; Gupta, A.; Sharma, S.; Gilbert, J.A.; Ahmad, P. Current developments in arbuscular mycorrhizal fungi research and its role in salinity stress alleviation: A biotechnological perspective. Crit. Rev. Biotechnol. 2015, 35, 461-474. [CrossRef] [PubMed]

31. Kumar, K.; Manigundan, K.; Amaresan, N. Influence of salt tolerant Trichoderma spp. on growth of maize (Zea mays) under different salinity conditions. J. Basic Microbiol. 2017, 57, 141-150. [CrossRef] [PubMed]

32. Etesami, H.; Maheshwari, D.K. Use of plant growth promoting rhizobacteria (PGPRs) with multiple plant growth promoting traits in stress agriculture: Action mechanisms and future prospects. Ecotoxicol. Environ. Saf. 2018, 156, 225-246. [CrossRef] [PubMed]

33. Shameer, S.; Prasad, T.N.V.K.V. Plant growth promoting rhizobacteria for sustainable agricultural practices with special reference to biotic and abiotic stresses. Plant Growth Regul. 2018, 84, 603-615. [CrossRef]

34. Colla, G.; Rouphael, Y.; Di Mattia, E.; El-Nakhel, C.; Cardarelli, M. Co-inoculation of Glomus intraradices and Trichoderma atroviride acts as a biostimulant to promote growth, yield and nutrient uptake of vegetable crops. J. Sci. Food Agric. 2015, 95, 1706-1715. [CrossRef] [PubMed]

35. Albdaiwi, R.N.; Khyami-Horani, H.; Ayad, J.Y.; Alananbeh, K.M.; Al-Sayaydeh, R. Isolation and characterization of halotolerant plant growth promoting rhizobacteria from durum wheat (Triticum turgidum subsp. durum) cultivated in saline areas of the dead sea region. Oxid. Med. Cell. Longev. 2020, 10. [CrossRef] [PubMed]

36. Giovannetti, M.; Mosse, B. An evaluation of techniques for measuring vesicular arbuscular mycorrhizal infection in roots. New Phytol. 1980, 84, 489-500. [CrossRef]

37. López-Bucio, J.; Pelagio-Flores, R.; Herrera-Estrella, A. Trichoderma as biostimulant: Exploiting the multilevel properties of a plant beneficial fungus. Sci. Hortic. 2015, 196, 109-123. [CrossRef]

38. Rouphael, Y.; Franken, P.; Schneider, C.; Schwarz, D.; Giovannetti, M.; Agnolucci, M.; De Pascale, S.; Bonini, P.; Colla, G. Arbuscular mycorrhizal fungi act as biostimulants in horticultural crops. Sci. Hortic. 2015, 196, 91-108. [CrossRef]

39. Vorholt, J.A.; Vogel, C.; Carlström, C.I.; Müller, D.B. Establishing Causality: Opportunities of Synthetic Communities for Plant Microbiome Research. Cell Host Microbe 2017, 22, 142-155. [CrossRef]

40. Woo, S.L.; Pepe, O. Microbial consortia: Promising probiotics as plant biostimulants for sustainable agriculture. Front. Plant Sci. 2018, 9, 1801. [CrossRef] [PubMed]

41. Thomloudi, E.-E.; Tsalgatidou, P.C.; Douka, D.; Spantidos, T.-N.; Dimou, M.; Venieraki, A.; Katinakis, P. Multistrain versus single-strain plant growth promoting microbial inoculants-The compatibility issue. Hell. Plant Prot. J. 2019, 12, 61-77. [CrossRef]

42. Sarma, B.K.; Yadav, S.K.; Singh, S.; Singh, H.B. Microbial consortium-mediated plant defense against phytopathogens: Readdressing for enhancing efficacy. Soil Biol. Biochem. 2015, 87, 25-33. [CrossRef]

43. Ruzzi, M.; Aroca, R. Plant growth-promoting rhizobacteria act as biostimulants in horticulture. Sci. Hortic. 2015, 196, 124-134. [CrossRef]

44. Feller, C.; Bleiholder, H.; Buhr, L.; Hack, H.; Hess, M.; Klose, R.; Meier, U.; Stauss, R.; van den Boom, T.; Weber, E. Phanologische Entwicklungsstadien von Gemusepflanzen I. Zwiebel-, Wurzel-, Knollen-und Blattgemuse. Nachr. Dtsch. Pflanzenschutzd. 1995, 47, 193-205.

45. Feller, C.; Bleiholder, H.; Buhr, L.; Hack, H.; Hess, M.; Klose, R.; Meier, U.; Stauss, R.; van den Boom, T.; Weber, E. Phanologische Entwicklungsstadien von Gemusepflanzen II. Fruchtgemuse und Hulsenfruchte. Nachr. Dtsch. Pflanzenschutzd. 1995, 47, 217-232.

46. Fageria, N.K.; Baligar, V.C.; Li, Y.C. The role of nutrient efficient plants in improving crop yields in the twenty first century. J. Plant Nutr. 2008, 31, 1121-1157. [CrossRef] 
47. McGuire, R.G. Reporting of objective color measurements. HortScience 1992, 27, 1254-1255. [CrossRef]

48. Herrera, F.; Castillo, J.E.; Chica, A.F.; López Bellido, L. Use of municipal solid waste compost (MSWC) as a growing medium in the nursery production of tomato plants. Bioresour. Technol. 2008, 99, 287-296. [CrossRef]

49. Russo, V.M. Biological amendment, fertilizer rate, and irrigation frequency for organic Bll pepper transplant production. HortScience 2006, 41, 1402-1407. [CrossRef]

50. McCall, D. Effect of supplementary light on tomato transplant growth, and the after-effects on yield. Sci. Hortic. 1992, 51, 65-70. [CrossRef]

51. Masson, J.; Tremblay, N.; Gosselin, A. Effects of nitrogen fertilization and HPS supplementary lighting on vegetable transplant production. II. Yield. J. Am. Soc. Hortic. Sci. 1991, 116, 599-602. [CrossRef]

52. Nicola, S.; Cantliffe, D.J. Increasing cell size and reducing medium compression enhance lettuce transplant quality and field production. HortScience 1996, 31, 184-189. [CrossRef]

53. Chen, J.; Huang, Y.; Caldwell, R.D. Best management practices for minimizing nitrate leaching from container-grown nurseries. Sci. World J. 2001, 1, 96-102. [CrossRef]

54. Shahbaz, M.; Ashraf, M.; Al-Qurainy, F.; Harris, P.J.C. Salt Tolerance in Selected Vegetable Crops. CRC Crit. Rev. Plant Sci. 2012, 31, 303-320. [CrossRef]

55. Shannon, M.C.; Grieve, C.M. Tolerance of vegetable crops to salinity. Sci. Hortic. 1998, 78, 5-38. [CrossRef]

56. Moncada, A.; Vetrano, F; Miceli, A. Alleviation of Salt Stress by Plant Growth-Promoting Bacteria in Hydroponic Leaf Lettuce. Agronomy 2020, 10, 1523. [CrossRef]

57. Grieve, C.M.; Grattan, S.R.; Maas, E.V. Plant salt tolerance. Agric. Salin. Assess. Manag. 2012, 2, 405-459.

58. FAO Drainage Paper 61, Agricultural Drainage Water Management in Arid and Semi-Arid Areas, Annex 1. Crop Salt Tolerance Data. Available online: http:/ / www.fao.org/3/y4263e/y4263e0e.htm (accessed on 10 September 2020).

59. Cuartero, J.; Fernández-Muñoz, R. Tomato and salinity. Sci. Hortic. 1998, 78, 83-125. [CrossRef]

60. Souri, M.K.; Tohidloo, G. Effectiveness of different methods of salicylic acid application on growth characteristics of tomato seedlings under salinity. Chem. Biol. Technol. Agric. 2019, 6, 26. [CrossRef]

61. Andriolo, J.L.; da Luz, G.L.; Witter, M.H.; Godoi, R.d.S.; Barros, G.T.; Bortolotto, O.C. Growth and yield of lettuce plants under salinity. Hortic. Bras. 2005, 23, 931-934. [CrossRef]

62. Ünlükara, A.; Cemek, B.; Karaman, S.; Erşahin, S. Response of lettuce (Lactuca sativa var. crispa) to salinity of irrigation water. New Zeal. J. Crop Hortic. Sci. 2008, 36, 265-273. [CrossRef]

63. Rosas, J.T.F.; Junior, E.M.; Lorenzoni, R.M.; dos Santos, F.F.L.; Martins, R.N. Effect of Salinity on Germination of Lettuce Cultivars Produced in Brazil. J. Exp. Agric. Int. 2019, 34, 1-8. [CrossRef]

64. Le Rudulier, D. Osmoregulation in rhizobia: The key role of compatible solutes. Grain Legum. 2005, 42, 18-19.

65. Srivastava, J.P.; Gupta, S.C.; Lal, P.; Muralia, R.N.; Kumar, A. Effect of salt stress on physiological and biochemical parameters of wheat. Annu. Arid Zo. 1988, 27, 197-204.

66. Shalhevet, J. Plants under salt and water stress. In Plant Adaptation to Environmental Stress; Fowden, L., Mansfield, T., Stoddart, J., Eds.; Chapman and Hall: London, UK, 1993; p. 133.

67. Shao, J.; Xu, Z.; Zhang, N.; Shen, Q.; Zhang, R. Contribution of indole-3-acetic acid in the plant growth promotion by the rhizospheric strain Bacillus amyloliquefaciens SQR9. Biol. Fertil. Soils 2015, 51, 321-330. [CrossRef]

68. Joo, G.-J.; Kim, Y.-M.; Lee, I.-J.; Song, K.-S.; Rhee, I.-K. Growth promotion of red pepper plug seedlings and the production of gibberellins by Bacillus cereus, Bacillus macroides and Bacillus pumilus. Biotechnol. Lett. 2004, 26, 487-491. [CrossRef]

69. Olanrewaju, O.S.; Babalola, O.O. Streptomyces: Implications and interactions in plant growth promotion. Appl. Microbiol. Biotechnol. 2019, 103, 1179-1188. [CrossRef]

70. Arkhipova, T.N.; Veselov, S.U.; Melentiev, A.I.; Martynenko, E.V.; Kudoyarova, G.R. Ability of bacterium Bacillus subtilis to produce cytokinins and to influence the growth and endogenous hormone content of lettuce plants. Plant Soil 2005, 272, 201-209. [CrossRef]

71. Chowdhury, S.P.; Dietel, K.; Rändler, M.; Schmid, M.; Junge, H.; Borriss, R.; Hartmann, A.; Grosch, R. Effects of Bacillus amyloliquefaciens FZB42 on lettuce growth and health under pathogen pressure and its impact on the rhizosphere bacterial community. PLoS ONE 2013, 8, e68818. [CrossRef]

72. Radhakrishnan, R.; Lee, I.-J. Gibberellins producing Bacillus methylotrophicus KE2 supports plant growth and enhances nutritional metabolites and food values of lettuce. Plant Physiol. Biochem. 2016, 109, 181-189. [CrossRef] [PubMed]

73. Kasozi, N.; Kaiser, H.; Wilhelmi, B. Effect of Bacillus spp. on Lettuce Growth and Root Associated Bacterial Community in a Small-Scale Aquaponics System. Agronomy 2021, 11, 947. [CrossRef]

74. Mehta, P.; Walia, A.; Kulshrestha, S.; Chauhan, A.; Shirkot, C.K. Efficiency of plant growth-promoting P-solubilizing Bacillus circulans CB7 for enhancement of tomato growth under net house conditions. J. Basic Microbiol. 2015, 55, 33-44. [CrossRef] [PubMed]

75. Dhouib, H.; Zouari, I.; Ben Abdallah, D.; Belbahri, L.; Taktak, W.; Triki, M.A.; Tounsi, S. Potential of a novel endophytic Bacillus velezensis in tomato growth promotion and protection against Verticillium wilt disease. Biol. Control 2019, 139, 104092. [CrossRef]

76. Walia, A.; Mehta, P.; Chauhan, A.; Shirkot, C.K. Effect of Bacillus subtilis strain CKT1 as inoculum on growth of tomato seedlings under net house conditions. Proc. Natl. Acad. Sci. India Sect. B Biol. Sci. 2014, 84, 145-155. [CrossRef] 
77. Masood, S.; Zhao, X.Q.; Shen, R.F. Bacillus pumilus promotes the growth and nitrogen uptake of tomato plants under nitrogen fertilization. Sci. Hortic. 2020, 272, 109581. [CrossRef]

78. Palaniyandi, S.; Damodharan, K.; Yang, S.; Suh, J. Streptomyces sp. strain PGPA39 alleviates salt stress and promotes growth of 'Micro Tom' tomato plants. J. Appl. Microbiol. 2014, 117, 766-773. [CrossRef]

79. Richardson, A.E.; Barea, J.-M.; McNeill, A.M.; Prigent-Combaret, C. Acquisition of phosphorus and nitrogen in the rhizosphere and plant growth promotion by microorganisms. Plant Soil 2009, 321, 305-339. [CrossRef]

80. Miceli, A.; Romano, C.; Moncada, A.; Piazza, G.; Torta, L.; D'Anna, F.; Vetrano, F. Yield and quality of mini-watermelon as affected bygrafting and mycorrhizal inoculum. J. Agric. Sci. Technol. 2016, 18, 505-516.

81. Baum, C.; El-Tohamy, W.; Gruda, N. Increasing the productivity and product quality of vegetable crops using arbuscular mycorrhizal fungi: A review. Sci. Hortic. 2015, 187, 131-141. [CrossRef]

82. Desai, S.; Bagyaraj, D.J.; Ashwin, R. Inoculation with microbial consortium promotes growth of tomato and capsicum seedlings raised in pro trays. Proc. Natl. Acad. Sci. India Sect. B Biol. Sci. 2020, 90, 21-28. [CrossRef]

83. Desai, S.; Kumar, G.P.; Amalraj, L.D.; Bagyaraj, D.J.; Ashwin, R. Exploiting PGPR and AMF Biodiversity for Plant Health Management. In Microbial Inoculants in Sustainable Agricultural Productivity; Springer: New Delhi, India, 2016; pp. 145-160. ISBN 978-8-13222-647-5.

84. Kohler, J.; Caravaca, F.; Carrasco, L.; Roldan, A. Interactions between a plant growth-promoting rhizobacterium, an AM fungus and a phosphate-solubilising fungus in the rhizosphere of Lactuca sativa. Appl. Soil Ecol. 2007, 35, 480-487. [CrossRef]

85. Ważny, R.; Rozpądek, P.; Jędrzejczyk, R.J.; Śliwa, M.; Stojakowska, A.; Anielska, T.; Turnau, K. Does co-inoculation of Lactuca serriola with endophytic and arbuscular mycorrhizal fungi improve plant growth in a polluted environment? Mycorrhiza 2018, 28, 235-246. [CrossRef]

86. Aroca, R.; Ruiz-Lozano, J.M.; Zamarreño, Á.M.; Paz, J.A.; García-Mina, J.M.; Pozo, M.J.; López-Ráez, J.A. Arbuscular mycorrhizal symbiosis influences strigolactone production under salinity and alleviates salt stress in lettuce plants. J. Plant Physiol. 2013, 170, 47-55. [CrossRef] [PubMed]

87. Rouphael, Y.; Cardarelli, M.; Bonini, P.; Colla, G. Synergistic Action of a Microbial-based Biostimulant and a Plant Derived-Protein Hydrolysate Enhances Lettuce Tolerance to Alkalinity and Salinity. Front. Plant Sci. 2017, 8, 131. [CrossRef]

88. Sellitto, V.M.; Golubkina, N.A.; Pietrantonio, L.; Cozzolino, E.; Cuciniello, A.; Cenvinzo, V.; Florin, I.; Caruso, G. Tomato yield, quality, mineral composition and antioxidants as affected by beneficial microorganisms under soil salinity induced by balanced nutrient solutions. Agriculture 2019, 9, 110. [CrossRef]

89. Woitke, M.; Junge, H.; Schnitzler, W.H. Bacillus Subtilis as Growth Promotor in Hydroponically Grown Tomatoes under Saline Conditions. Acta Hortic. 2004, 363-369. [CrossRef]

90. Cortés-Jiménez, D.; Gómez-Guzmán, A.; Iturriaga, G.; Suárez, R.; Montero Alpírez, G.; Escalante, F.M.E. Microorganisms associated to tomato seedlings growing in saline culture act as osmoprotectant. Braz. J. Microbiol. 2014, 45, 613-620. [CrossRef]

91. Machado, R.; Serralheiro, R. Soil Salinity: Effect on Vegetable Crop Growth. Management Practices to Prevent and Mitigate Soil Salinization. Horticulturae 2017, 3, 30. [CrossRef]

92. Egamberdieva, D.; Lugtenberg, B. Use of plant growth-promoting rhizobacteria to alleviate salinity stress in plants. In Use of Microbes for the Alleviation of Soil Stresses; Springer: New York, NY, USA, 2014; Volume 1, pp. 73-96. ISBN 978-1-46149-466-9.

93. Munns, R.; James, R.A.; Läuchli, A. Approaches to increasing the salt tolerance of wheat and other cereals. J. Exp. Bot. 2006, 57, 1025-1043. [CrossRef]

94. Kaushal, M.; Wani, S.P. Plant-growth-promoting rhizobacteria: Drought stress alleviators to ameliorate crop production in drylands. Ann. Microbiol. 2016, 66, 35-42. [CrossRef]

95. Jyothsna, P.; Murthy, S.D.S. A review on effect of senescence in plants and the role of phytohormones in delaying senescence. Int. J. Plant Anim. Environ. Sci. 2016, 6, 152-161.

96. Paul, D.; Lade, H. Plant-growth-promoting rhizobacteria to improve crop growth in saline soils: A review. Agron. Sustain. Dev. 2014, 34, 737-752. [CrossRef]

97. Vanderlinde, E.M.; Harrison, J.J.; Muszyński, A.; Carlson, R.W.; Turner, R.J.; Yost, C.K. Identification of a novel ABC transporter required for desiccation tolerance, and biofilm formation in Rhizobium leguminosarum bv. viciae 3841. FEMS Microbiol. Ecol. 2010. [CrossRef]

98. Yang, J.; Kloepper, J.W.; Ryu, C.-M. Rhizosphere bacteria help plants tolerate abiotic stress. Trends Plant Sci. 2009, 14, 1-4. [CrossRef]

99. Feng, G.; Zhang, F.; Li, X.; Tian, C.; Tang, C.; Rengel, Z. Improved tolerance of maize plants to salt stress by arbuscular mycorrhiza is related to higher accumulation of soluble sugars in roots. Mycorrhiza 2002, 12, 185-190. [CrossRef]

100. Al-Karaki, G.N.; Hammad, R.; Rusan, M. Response of two tomato cultivars differing in salt tolerance to inoculation with mycorrhizal fungi under salt stress. Mycorrhiza 2001, 11, 43-47. [CrossRef]

101. Abdel Latef, A.A.H.; Chaoxing, H. Effect of arbuscular mycorrhizal fungi on growth, mineral nutrition, antioxidant enzymes activity and fruit yield of tomato grown under salinity stress. Sci. Hortic. 2011, 127, 228-233. [CrossRef]

102. Zuccarini, P. Mycorrhizal infection ameliorates chlorophyll content and nutrient uptake of lettuce exposed to saline irrigation. Plant Soil Environ. 2008, 53, 283-289. [CrossRef] 
103. Hameed, A.; Dilfuza, E.; Abd-Allah, E.F.; Hashem, A.; Kumar, A.; Ahmad, P. Salinity Stress and Arbuscular Mycorrhizal Symbiosis in Plants. In Use of Microbes for the Alleviation of Soil Stresses; Springer: New York, NY, USA, 2014; Volume 1, pp. 139-159. ISBN 978-1-46149-466-9.

104. Porcel, R.; Aroca, R.; Ruiz-Lozano, J.M. Salinity stress alleviation using arbuscular mycorrhizal fungi. A review. Agron. Sustain. Dev. 2012, 32, 181-200. [CrossRef]

105. Jahromi, F.; Aroca, R.; Porcel, R.; Ruiz-Lozano, J.M. Influence of Salinity on the In Vitro Development of Glomus intraradices and on the In Vivo Physiological and Molecular Responses of Mycorrhizal Lettuce Plants. Microb. Ecol. 2008, 55, 45-53. [CrossRef]

106. Porcel, R.; Azcón, R.; Ruiz-Lozano, J.M. Evaluation of the role of genes encoding for dehydrin proteins (LEA D-11) during drought stress in arbuscular mycorrhizal Glycine max and Lactuca sativa plants. J. Exp. Bot. 2005, 56, 1933-1942. [CrossRef]

107. Mastouri, F.; Björkman, T.; Harman, G.E. Seed treatment with Trichoderma harzianum alleviates biotic, abiotic, and physiological stresses in germinating seeds and seedlings. Phytopathology 2010, 100, 1213-1221. [CrossRef] [PubMed]

108. Shoresh, M.; Harman, G.E.; Mastouri, F. Induced systemic resistance and plant responses to fungal biocontrol agents. Annu. Rev. Phytopathol. 2010, 48, 21-43. [CrossRef] [PubMed]

109. Contreras-Cornejo, H.A.; Macías-Rodríguez, L.; Alfaro-Cuevas, R.; López-Bucio, J. Trichoderma spp. improve growth of Arabidopsis seedlings under salt stress through enhanced root development, osmolite production, and Na+ elimination through root exudates. Mol. Plant Microbe Interact. 2014, 27, 503-514. [CrossRef]

110. Zhang, S.; Gan, Y.; Xu, B. Application of plant-growth-promoting fungi Trichoderma longibrachiatum T6 enhances tolerance of wheat to salt stress through improvement of antioxidative defense system and gene expression. Front. Plant Sci. 2016, 7, 1405. [CrossRef]

111. Mastouri, F.; Björkman, T.; Harman, G.E. Trichoderma harzianum enhances antioxidant defense of tomato seedlings and resistance to water deficit. Mol. Plant Microbe Interact. 2012, 25, 1264-1271. [CrossRef]

112. Ahmad, P.; Hashem, A.; Abd-Allah, E.F.; Alqarawi, A.A.; John, R.; Egamberdieva, D.; Gucel, S. Role of Trichoderma harzianum in mitigating $\mathrm{NaCl}$ stress in Indian mustard (Brassica juncea L) through antioxidative defense system. Front. Plant Sci. 2015, 6, 868. [CrossRef] [PubMed]

113. Martínez-Medina, A.; Roldán, A.; Albacete, A.; Pascual, J.A. The interaction with arbuscular mycorrhizal fungi or Trichoderma harzianum alters the shoot hormonal profile in melon plants. Phytochemistry 2011, 72, 223-229. [CrossRef] [PubMed]

114. Bais, H.P.; Weir, T.L.; Perry, L.G.; Gilroy, S.; Vivanco, J.M. The role of root exudates in rhizosphere interactions with plants and other organisms. Annu. Rev. Plant Biol. 2006, 57, 233-266. [CrossRef] [PubMed]

115. Hartmann, A.; Schmid, M.; van Tuinen, D.; Berg, G. Plant-driven selection of microbes. Plant Soil 2009, 321, 235-257. [CrossRef]

116. Hardoim, P.R.; van Overbeek, L.S.; van Elsas, J.D. Properties of bacterial endophytes and their proposed role in plant growth. Trends Microbiol. 2008, 16, 463-471. [CrossRef] [PubMed]

117. Bagyaraj, D.J. Mycorrhizal fungi. Proc. Indian Natl. Sci. Acad. 2014, 80, 415-428. [CrossRef]

118. Raklami, A.; Bechtaoui, N.; Tahiri, A.; Anli, M.; Meddich, A.; Oufdou, K. Use of Rhizobacteria and Mycorrhizae Consortium in the Open Field as a Strategy for Improving Crop Nutrition, Productivity and Soil Fertility. Front. Microbiol. 2019, 10, 1106. [CrossRef]

119. Panwar, M.; Tewari, R.; Nayyar, H. Microbial Consortium of Plant Growth-Promoting Rhizobacteria Improves the Performance of Plants Growing in Stressed Soils: An Overview. In Phosphate Solubilizing Microorganisms; Springer International Publishing: Cham, Switzerland, 2014; pp. 257-285. ISBN 978-3-31908-216-5. 